\title{
Herbal Hepatotoxicity: Clinical Characteristics and Listing Compilation
}

\author{
Christian Frenzel ${ }^{1, *}$ and Rolf Teschke ${ }^{2}$ \\ 1 Department of Medicine I, University Medical Center Hamburg Eppendorf, Martinistrasse 52, \\ D-20246 Hamburg, Germany \\ 2 Department of Internal Medicine II, Division of Gastroenterology and Hepatology, Klinikum Hanau, \\ Teaching Hospital of the Medical Faculty, Goethe University Frankfurt/Main, 63450 Hanau, Germany; \\ rolf.teschke@gmx.de \\ * Correspondence: cfrenzel@uke.de; Tel.: +49-40-7410-53910; Fax: +49-40-7410-58531
}

Academic Editor: Tatsuo Kanda

Received: 7 March 2016; Accepted: 11 April 2016; Published: 27 April 2016

\begin{abstract}
Herb induced liver injury (HILI) and drug induced liver injury (DILI) share the common characteristic of chemical compounds as their causative agents, which were either produced by the plant or synthetic processes. Both, natural and synthetic chemicals are foreign products to the body and need metabolic degradation to be eliminated. During this process, hepatotoxic metabolites may be generated causing liver injury in susceptible patients. There is uncertainty, whether risk factors such as high lipophilicity or high daily and cumulative doses play a pathogenetic role for HILI, as these are under discussion for DILI. It is also often unclear, whether a HILI case has an idiosyncratic or an intrinsic background. Treatment with herbs of Western medicine or traditional Chinese medicine (TCM) rarely causes elevated liver tests (LT). However, HILI can develop to acute liver failure requiring liver transplantation in single cases. HILI is a diagnosis of exclusion, because clinical features of HILI are not specific as they are also found in many other liver diseases unrelated to herbal use. In strikingly increased liver tests signifying severe liver injury, herbal use has to be stopped. To establish HILI as the cause of liver damage, RUCAM (Roussel Uclaf Causality Assessment Method) is a useful tool. Diagnostic problems may emerge when alternative causes were not carefully excluded and the correct therapy is withheld. Future strategies should focus on RUCAM based causality assessment in suspected HILI cases and more regulatory efforts to provide all herbal medicines and herbal dietary supplements used as medicine with strict regulatory surveillance, considering them as herbal drugs and ascertaining an appropriate risk benefit balance.
\end{abstract}

Keywords: hepatotoxicity; herbal drug; herb induced liver injury (HILI); herbal hepatotoxicity

\section{Introduction}

There are worldwide efforts aiming to develop drugs from natural products. Such successful drug developments were recently honored by awarding the Nobel Prize for Medicine and Physiology 2015 for the discovery of two natural products that brought breakthroughs in the therapy of tropical parasitic diseases affecting millions of individuals worldwide. Youyou Tu received the price for her discovery of artemisinin for the treatment of malaria, and William C. Campbell and Satoshi ômura for their discovery of the avermectins for the treatment of helminthic diseases. In the context of herbal medicine, artemisinin is derived from the herbal Traditional Chinese Medicine (TCM) Artemisia annua, known for more than two thousand years as a Chinese herbal medicine for various ailments [1-3]. Artemisinin and its derivatives such as artesunate and arthemeter are successfully used to treat patients with malaria alone or in combination with other antimalarial drugs, and they are also effective against cancer cells and schistosomiasis [3]. Many other drugs have been developed from herbs of traditional or 
modern medicine [4]. Among these drugs are acetylsalicylic acid derived from the willow tree, atropine from Duboisia myoporoides, belladonna from Atropa belladonna, casanthranol from Rhamnus purhiana, cholchicine from Colchicum autumnale, digitoxine from Digitalis purpurea, digoxine from Digitalis lanata, ephedrine from Ephedra sinica, etoposide from Podophyllum peltatum, morphine from Papaver somniferum, paclitaxel from Taxus brevifolia or Taxus baccata, papain from Carica papaya, papaverine from Papaver somniferum, quinine from Cinchona species, reserpine from Rauwolfia serpentine, and vincristine from Catharanthus roseus. In the future, herbal medicinal products will have a potential to advance drug discovery and development in a major world market, which stands at about $\$ 83$ billion and Europe accounts for over $50 \%$ of the total [5]. Impressing data are reported for China, where the use of herbal medicines represents around $40 \%$ of all health care services [6]. In other countries such as Australia, Canada, USA, Belgium, and France, the percentage of the population that has used herbal medicines at least once is estimated at $38 \%-75 \%$.

Key issues of presently available and newly developed herbal medicines will have to focus on questions as to whether the benefit risk balance is appropriate [7] and on monitoring safety [6]. This should be associated with mandatory causality assessment of adverse reactions [6-8], especially related to the liver as the target organ [8-11]. Clinical and causality assessment in patients with suspected herbal hepatotoxicity or its synonym herb induced liver injury (HILI) is facilitated as specific approaches are identical or at least very similar to those of drug induced liver injury (DILI) [8,12].

In this review article, we will discuss typical features of HILI cases and provide a list of published case reports on HILI by various herbs including herbal TCM. We will also consider the problem of valid causality assessments and propose clinical and regulatory strategies to minimize the risk for patient with assumed HILI.

\section{Data Sources and Searches}

\subsection{Search Terms}

We searched the PubMed database to identify publications of case reports, case series, and review articles for the following terms: "herbs", "herb induced liver injury", and "herbal hepatotoxicity". This allowed the identification of publications on herbal hepatotoxicity and herb induced liver injury which each provided hits of around 280,000 and 3,010,000, respectively. Our search was then extended further using additional keywords denoting herbal modern medicine and herbal traditional Chinese medicine, TCM, providing additional hits. The first 100 hits of publications in each category were commonly considered.

In addition, to ensure that articles of high quality were considered, we used our actualized personal scientific archives, which contain original full-length publications relating to HILI covering the years from 1990 to early 2016.

\subsection{Data Extraction}

Prior to our analysis, the publications were assessed regarding their scientific quality. To meet requirements, articles had to include a clinical case description with history and symptoms, provide laboratory data and delineate the outcome of HILI. Publications of relevance and good quality were considered for evaluation. Our search focused on publications in English language, but few reports in other languages were also considered if they were of significant clinical importance and added to present knowledge. The literature search was limited since many reports of HILI by herbal TCM were in Chinese without an English abstract. Consequently, these Chinese publications were outside the focus of our present review article. Publications were also searched manually for additional publications not yet identified. The literature search ended on 15 February 2016. 


\section{Variability of Herbal Product Types}

Among the most frequently used herbal products in the world are green and black tea [13], herbal traditional medicines $[8,9,14]$, and herbal dietary supplements (HDS) [11], while the proportion of herbal drugs manufactured and controlled according to regulation guidelines appears to be smaller $[6,14]$. With the exception of the popular green and black tea that are commonly well tolerated if not consumed as tea extract [7], the use of the other herbal products may cause various rare adverse effects [6] including serious ones affecting the liver [8-11]. The regulatory status of these herbal products differs from country to country $[6,11,14]$.

\section{Herbal Product Quality}

With the exemption of most herbal drugs under strict regulatory surveillance, some other herbal products that are manufactured for human use may suffer from quality problems (Table 1) [15]. Adherence to the quality criteria of current Good Agricultural Practices (cGAPs) and current Good Manufacturing Practices (cGMPs) is mandatory to ensure consumer safety. It is often speculative and unclear to what extent a problematic product quality is responsible for a liver disease of a patient who consumed such a product if HILI is not established as valid diagnosis.

Table 1. Minimum quality requirements for herbs, herbal drugs, and herbal dietary supplements in the context with suspected herb induced liver injury (HILI) cases.

\begin{tabular}{ll}
\hline Item & Product Quality Specifications \\
\hline \multirow{3}{*}{ Herbal product declarations } & $\begin{array}{l}\text { Declaration of the manufacturer with address, phone and fax } \\
\text { number, e-mail } \\
\text { Expiration date of the herbal drug and herbal supplement } \\
\text { Batch number } \\
\text { Correct labelling of all ingredients }\end{array}$ \\
\hline \multirow{3}{*}{ Herbal product definitions } & Definition of plant family, subfamily, species, subspecies, and variety \\
& Definition of plant part \\
& Definition of used solvents and solubilizers \\
\hline \multirow{3}{*}{ Herbal quality standards } & Exclusion of impurities, adulterants, and misidentifications \\
& Minimum or lack of batch to batch variability \\
& Minimum or lack of product to product variability \\
& Lack of variety to variety variability \\
& Current Good Agricultural Practices (cGAPs) \\
& Current Good Manufacturing Practices (cGMPs) \\
& Regulatory surveillance \\
\hline \multirow{2}{*}{ Consumer information } & Detailed recommendation for indication and contraindication \\
& Advice for daily dose and maximum use duration \\
\hline & Adapted from a previous report [8]
\end{tabular}

\subsection{Plant Identification and Its Parts}

Any herbal product needs a clear definition and identification of plant family, subfamily, species, subspecies, and variety. This information should follow classical botanical descriptions and requirements for any herb used. Disregard may cause variation in plant family and species, contributing to the overall batch and product variability. Information of the individual herb identification items is best provided by the manufacturers in the package leaflet that should be available to the physician who suspects HILI. Such leaflets usually contain the name of the herbal product and the address of the manufacturer who will provide additional information upon request. Therefore, all essential data of herb identification and the herbal product should be available before reporting HILI case details as spontaneous reports to regulatory agencies or as case report publication. However, pitfalls are evident already at this stage of case evaluation [15]. 


\subsection{Misidentifications, Adulterants, and Impurities}

Plant misidentifications, adulterants, and impurities are known for a long time and still are key issues for herbal product quality [15-22]. Plant misidentification remains undisclosed for consumers who believe that the herbal product they use contains correct herbal ingredients as labeled. Herbal products containing misidentified plants impose a high risk for the unaware consumer. Chemical compounds as adulterants are problematic for the consumers if they are not labeled as such. Such unlabeled adulterants have to be classified better as unlabeled contaminants, implying a risky product. Impurities are mostly a consequence of disregarding cGAPs and cGMPs (Table 1).

\subsubsection{Misidentifications}

A thorough regulatory report in Canada described analytical approaches in herbal products that were initially suspected as causative of some HILI cases, with the result that the suspected herb was not present in the products used by the affected patients [16]. This observation suggests that in a patient with suspected HILI causality cannot be ascertained without careful product analysis, which requires that the used herbal product is made available for testing. Mislabeling was also discovered in other herbal supplements after product analysis and comparing the results with the product labeling [22]. Green tea extracts (GTE) with catechins as their main ingredients have been implicated before as causes in some patients with HILI [23]. This led to regulatory statements by the United States Pharmacopeia [24] and analyses for catechins in herbal dietary supplements implicated in hepatotoxicity [22]. For 73 products, no GTE or catechins were identified on the label, implying that GTE was not considered as cause for the injury; yet for $29(40 \%)$ of these products, catechins were detectable, which might have caused the liver injury [22]. Therefore, mislabeling may lead to erroneous causality attribution, unless product analysis clarifies its correct ingredients. The specific problems with herbal dietary supplements in the context of possible HILI has been well summarized: the myriad available and often multiple implicated products, batch-to-batch and product-to-product variability, and the potential for interactions among ingredients within a product or with other medications frequently confound attribution of injury to any one product or ingredient [22].

Herbal misidentification is a complex condition and a major clinical challenge as it may harm dramatically the health of consumers. Until 2008, overall, 41 cases from China with hepatic sinusoidal obstruction syndrome (HSOS), the former hepatic venoocclusive disease (HVOD), were reported and causality was attributed to the herbal TCM Jing Tian San Qi (Sedum aizoon, syn. Stonecrop), but causal attribution to Sedum aizoon was obviously incorrect. Sedum aizoon lacks unsaturated pyrrolizidine alkaloids (PAs), and when applied to experimental animals, HSOS did not emerge [25], strongly suggesting that for the reported HSOS cases, PAs are responsible, which are contained in and provided by another herb [26]. In line with this is another hepatotoxicity case from Hong Kong with HSOS that was also ascribed to Sedum aizoon, but it turned out to have been caused by the herbal TCM Shan Chi (Gynura segetum) [26]. The name and appearance of Sedum aizoon is similar to the one of Gynura segetum, but botanical differentiation was considered possible for experts [26]. Finally, studies comparing both herbs provided clear evidence for Gynura segetum as culprit for additional cases of HSOS as compared to Sedum aizoon. Respective studies in rats showed that Gynura segetum contains PA and may cause experimental HSOS as assessed by liver histology; in contrast, PAs were not found in Sedum aizoon [26]. In an earlier experimental study, a model of the HSOS was established by PAs derived from a herb described erroneously as Sedum aizoon [27], which again does not contain PAs [26,28,29]. This suggests that the described experimental model [27] was due to the action of a herb, which contains PAs, most likely Gynura segetum [26,28,29], rather than Sedum aizoon that lacks PAs [28]. Based on these well founded considerations, evidence for a hepatotoxic potential of Jing Tian San Qi is lacking. The herbal TCM Sedum aizoon should therefore no longer be listed as a hepatotoxic herb, as done until recently [30].

Gynura segetum was involved in other cases of herbal misidentification. In two Chinese women, HSOS emerged, which was induced by PAs of the herbal TCM Gynura segetum (syn. Ju Shan Qi, 
Ju Ye San Qi, San Qi Cao, Shan Chi) [31]. Additional six cases were suspected earlier [32,33]; in at least four of these, the culprit was the PA containing herb Heliotropium lasiocarpum rather than Gynura segetum [34].

All these examples illustrate the difficulties to incorporate the correct herb into the herbal product. Users may not consume what is labeled and vice versa may use products with unlabeled ingredients. Unquestionably, a more stringent regulatory surveillance will lead to herbal products of good quality, providing thereby an improved consumer safety.

\subsubsection{Adulterants and Unlabeled Contaminants}

Heavy metals such as lead, mercury, cadmium, or arsenic may be found in some herbal medicines, added as adulterants due to the belief they could enhance the efficacy of the herbs in their products $[19,21,35-37]$. However, these heavy metals remain mostly unlabeled. In particular, lead is a regular constituent of traditional Indian remedies [35]. The incidence of contamination with heavy metals is unknown, but one study shows that $64 \%$ of samples collected in India contained significant amounts of lead, with corresponding figures for mercury $(64 \%)$, arsenic $(41 \%)$, and cadmium (9\%) [35]. Consequently, cases of heavy metal poisoning in connection with Ayurvedic medicine use have been continuously reported [38]. However, there is also the note that despite being widely used, hepatotoxicity from only a few Ayurvedic medicine products has been reported in the literature [38], referring to four publications [39-42]. Centella asiatica, an Ayurvedic medicine used mainly for leprosy, has been reported to cause granulomatous hepatitis and cirrhosis [39,40]. Severe hepatitis from prolonged intake of herbal Indian Ayurvedic products used for vitiligo has been reported by our group [41]. Additionally, in the large randomized controlled trial of the Ayurvedic herbal combination product Liv.52 [42] that contains capers, wild chicory, arjuna, black nightshade, yarrow, and others for the treatment of alcoholic liver cirrhosis [38], no effect on survival was observed in Child class A/B patients, but liver-related mortality was significantly increased after evaluation of the two-year survival [38,42], suggesting a potential detrimental effect of the Ayurvedic product [38].

Hepatotoxicity in consumers of the herbal TCM mixtures Chaso and Onshido was ascribed to $\mathrm{N}$-nitroso-fenfluramine, an unlabeled compound found in these slimming aid products that had been produced in China and sold in Japan and was discussed as an adulterant [43]. However, there is only little clinical or experimental evidence for a potential hepatotoxicity by this chemical compound, which was unlabeled and should better be classified as undisclosed contaminant [44-46], as discussed in detail in a previous report, which suggested that green tea extract as ingredient of these formulations is likely the causative agent [47]. Not provided by any supportive evidence is also the belief that 1.3-dimethylamine (DMAA), Aegeline, or both are hepatotoxic [11], which were labeled ingredients of other dietary supplements (DS) used by some liver patients, in whom overall hepatotoxicity causality for the DS themselves had to be denied [48-50].

Another group of adulterants refers to synthetic drugs, which are added to some herbal products to fortify therapeutic effects, but not all synthetic drug adulterants are labeled as such $[15,17,18]$. Adulterations with synthetic drugs was described especially for Chinese herbal medicines, with a long list of drugs commonly used for many indications in modern medicine [19,51]. Most disturbing was a study from Taiwan that showed that $24 \%$ of the samples were contaminated by at least one adulterant [16,51]. Overall, some of these adulterated drugs were harmful for the patients [51]. In this context, however, the question in these patients is as to whether the liver disease is a HILI by the consumed herbs or a DILI caused by the synthetic drug. As most synthetic drugs are well tolerated without liver injury by most individuals, DILI may be extremely rare in patients using these synthetic drugs contained in herbal products. Thus, herbs are more likely candidates for the toxic liver disease under these conditions.

It remains to be established to what extent also other problems of product quality such as plant misidentifications, adulterants and unlabeled contaminants are responsible for HILI, which must 
be clarified on a case by case basis. In fact, the possibility of contamination frequently confounds attribution of injury to any one product or ingredient [22].

\subsubsection{Impurities}

Most nature based herbal products are confronted with some risks of impurities such as aflatoxinosis evolving during their agricultural and manufacturing process of TCM herbs [52,53] and non-TCM herbs such as kava, Piper methysticum, a South Pacific medicinal plant [54]. On theoretical grounds, aflatoxins may contaminate kava plants due to the humid conditions and high temperatures of the South Pacific region [54-57]. These and other issues of impurities as well as additional uncertainties about the kava product quality led to analyses, discussions [58,59], and a proposal for a kava quality standard [60] to ultimately ensure all quality requirements of kava as herbal anxiolytic medicine [61-63]. Subsequently, this goal was achieved by providing good quality of kava to be used in clinical trials to treat patients with anxiety disorders, and kava therapy was found to be effective and safe [64-69].

\section{Pathogenetic Aspects of Herb Induced Liver Injury (HILI)}

\subsection{General Considerations}

Specific events leading to HILI are mostly unknown, as HILI is primarily a human and not an animal disease; experimental models to study in detail the mechanisms leading to injury are therefore rarely available. For some TCM herbs known to cause liver injury, various toxic substances have been proposed and are listed as examples (Table 2) [70]. The pathogenesis of hepatotoxicity by TCM herbs containing unsaturated PAs has been elucidated in experimental studies, which showed hepatic microsomal cytochrome P450 (CYP) to be involved in the activation of PAs [71]. Similarly, and due to its experimental reproducibility in animals, the molecular pathogenesis of Germander (Teucrium chamaedrys) hepatotoxicity can easily be studied and transferred to human Germander hepatotoxicity [72]. Germander components are neoclerodane diterpenoids that are oxidized by the CYP 3A isoform into reactive metabolites. These deplete hepatic stores of glutathione and cytoskeleton associated protein thiols, form plasma membrane blebs, and cause apoptosis of liver cells [72,73]. Many other reports suggest chemical ingredients as causes for various HILI cases, but these suggestions are often speculative for human HILI.

Table 2. Some examples of suspected toxic compounds as suggested causes of hepatotoxicity by herbal Traditional Chinese Medicine (TCM).

\begin{tabular}{lll}
\hline \multicolumn{1}{c}{ Chinese Name } & \multicolumn{1}{c}{ Scientific Name } & \multicolumn{1}{c}{ Tentative Hepatotoxic Components } \\
\hline Ai Ye & Artemisia argyi & Volatile oil \\
Bi Ma Zi & Rhicinus communis & Ricin, toxic proteins \\
Cang Shan & Xanthium & Glycosides (kaurene), diterpenoids \\
Chang Shan & Dichor febrifuga Lour & Alkaloids (dichroine) \\
He Huan Pi & Albizia julibrissin & Glycosides (saponine) \\
He Shou Wu & Polygonum multiflorum & Anthraquinones \\
Huang Yao Zi & Discorea bulbifera L & Glycosides (steroids, diosgenin), \\
& & diterpenoids-lactones \\
Ku Lian Zi & Melia azedarach & Glycosides (tetranortriterpenoids) \\
Lei Gong Teng & Tripterygium wilfordii hook F & Glycosides (tripterygium), diterpenoid-lactones \\
Qian Li Guang & Senecio scandens & Pyrrolizidine alkaloids \\
Shan Lu & Phytolacca acinosa Roxb. & Alkaloids (phytolaccine) \\
Xiang Si Zi & Abrus Precatorius & Abrin \\
\hline
\end{tabular}

Data are derived from a published report by Ma et al. [70].

As opposed to HILI, many more studies on pathogenetic aspects have been done in patients with DILI but it is uncertain whether such results are transferrable to HILI. For instance, recent DILI relevant data on actual pathogenetic hallmarks are directed to: (1) genome-wide association studies, 
which identified genetic predisposition as a relevant risk factor for liver injury [73,74]; (2) human leucocyte antigen (HLA) genotype as a strong risk factor for DILI, likely involving a drug-peptide adducts presented to T cells, although HLA alleles are only associated with some forms of DILI [73]; and (3) non-HLA genetic risk factors, which are thought to play a contributory role, especially those related to drug metabolism, detoxification, and disposition [73,74].

Involved genes may result in polymorphisms of bioactivation pathways via the CYP systems (Phase I reactions), conjugation reactions (Phase II), and excretion and transport (Phase III) [74]. For some drugs, even a dual role of HLA and drug metabolism genes is under consideration [73]. Other pathogenetic aspects related to DILI are still under discussion, in particular risk factors such as high lipophilicity and high daily doses of oral medications [75,76].

\subsection{Idiosyncratic and Intrinsic HILI}

Every HILI case report should include data relevant for a pathogenetic case classification, using appropriate criteria that characterize the different types of HILI (Figure 1). In analogy to DILI, HILI is best described by its two types, the idiosyncratic HILI and the intrinsic HILI [77]. Idiosyncratic HILI is typically caused by herbs at therapeutic dosages through an idiosyncratic and thereby unpredictable reaction, which may be either metabolic or immunologic, as opposed to intrinsic HILI that develops from predictable reactions due to overdosed herbal products (Figure 1).

Because typical features show some overlap (Figure 1), few HILI cases may be ascribed to both idiosyncratic and intrinsic injury, especially when herbal product quality is different regarding toxic ingredients. Although valid data are lacking, it appears that most HILI cases are of the idiosyncratic rather than the intrinsic type. Overall, most plants are fairly well tolerated by humans, whether used as normal food, beverage, herbal drugs, or HDS.

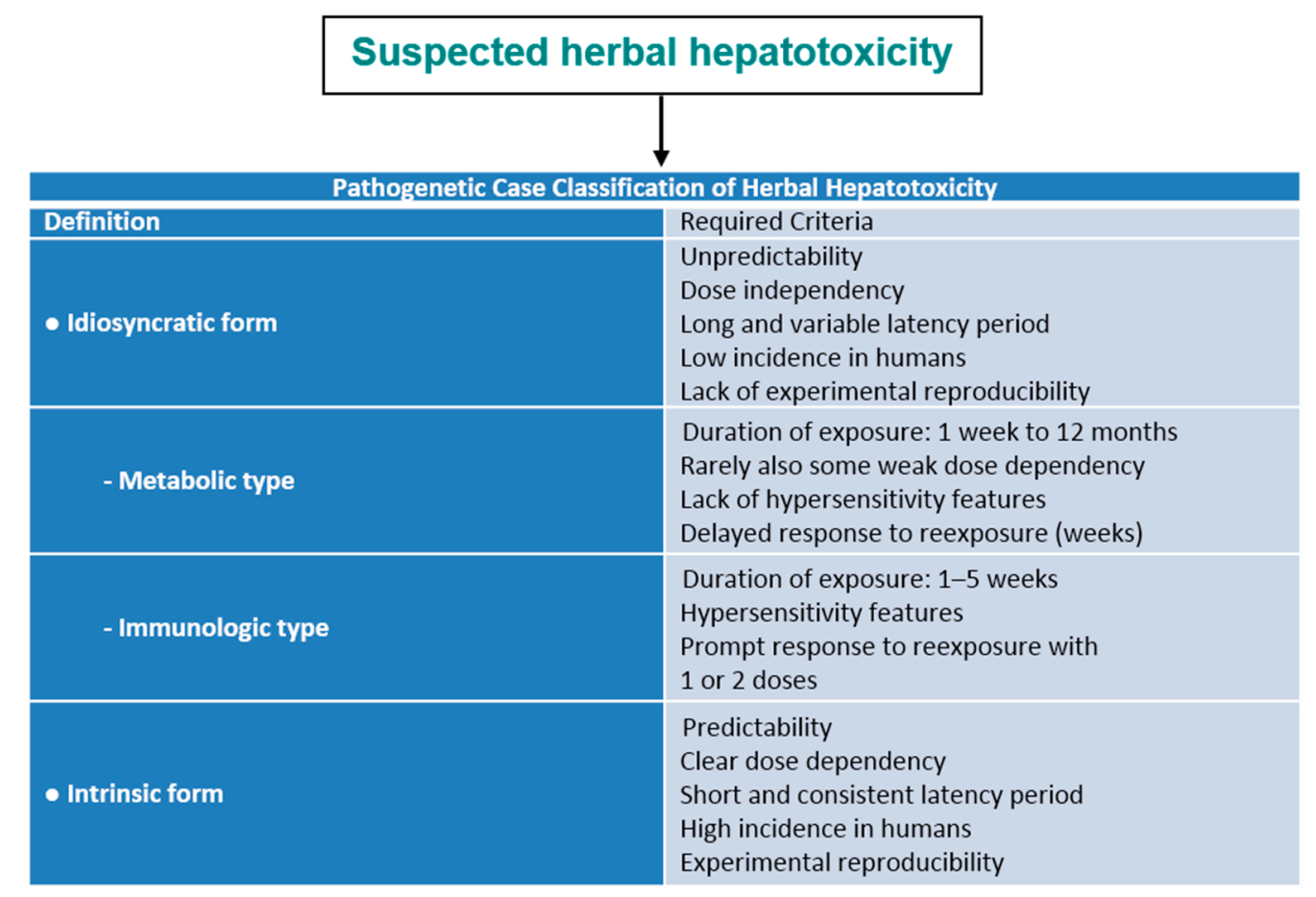

Figure 1. Pathogenetic classification of HILI. Data adapted from a previous report [8].

\subsubsection{Idiosyncratic HILI Type}

A good example of the idiosyncratic HILI type is the hepatotoxicity by Greater Celandine (GC) (Table 3) with its metabolic subtype [78] in reference to case details presented in previous reports [78,79]. GC hepatotoxicity is not reproducible in experimental animal models. 
Table 3. Clinical characteristics of HILI by Greater Celandine.

\begin{tabular}{l}
\hline Items \\
\hline - Background \\
\hline - RUCAM \\
- Comedication causality \\
assessment by RUCAM \\
- Positive reexposure result \\
- Age and gender \\
\hline - High comedication rate \\
\hline$\bullet$ Chelidonine dose adherence \\
\hline$\bullet$ Variable treatment duration \\
\hline symptoms
\end{tabular}

Jaundice as major symptom of GC induced HILI

\section{Clinical Characteristics of HILI by Greater Celandine (GC)}

1. Clinical characterization of HILI by GC as a specific disease entity was feasible and based on 16 patients with liver disease and high causality levels for GC;

2. RUCAM based causality for GC was graded highly probable in 4 patients and probable in 12 patients;

3. Among these 16 patients, there was an additional RUCAM based causality for comedication with curcuma graded as possible, for comedication with Lycopodium serratum graded as probable, and for biliary disease graded as possible;

4. The existence of GC HILI has been verified by a positive reexposure test in two patients;

5. Ages of the 16 patients ranged from 32 to 69 years with an average of 54.7 years, and the ratio of females: males was 10: 6;

6. Comedication with synthetic or herbal drugs and dietary supplements and herbal mixtures was used in the majority of assessable cases;

7. On average, the patients used $10 \mathrm{mg}$ chelidonine daily, with no reported overdose in any of the cases;

8. Treatment duration was 3 weeks to 9 months with an average of 2.4 months;

9. Latency period until first symptoms was 3 weeks to 4.5 months with an average of 1.7 months, which was considerably shorter than the treatment length;

10. Jaundice was the most frequently reported symptom, rarely also weakness, anorexia, nausea, vomiting, abdominal pains, dark urine, pale stools, and itching;

- Hepatocellular liver injury

11. High serum activities are found for ALT but not for ALP, suggestive of hepatocellular liver injury in patients with GC HILI;

Liver histology 12. Histology showed predominantly liver cell necrosis and hepatitis;

13. Outcome was favorable in all 16 patients, with lack of both acute liver failure and requirement of a liver transplant;

- Favorable outcome

14. In one patient, good prognosis was sustained even after 7 months of

- Good prognosis despite continued GC intake continued GC use despite presence of emerging GC HILI;

- Idiosyncratic liver injury with its metabolic subgroup

15. GC HILI usually represents the hepatocellular and idiosyncratic type of liver injury with its metabolic subgroup, characterized as acute clinical course;

- Individual culprits still undetermined

16. The underlying mechanism(s) leading to GC hepatotoxicity as well as possible culprit(s) are still unknown;

- Safety concern

17. In cases of liver disease, causality for GC was verified and creates concern regarding safety of patients;

- GC HILI likely with low incidence

18. Lacking valid epidemiologic data, but incidence of GC HILI is likely low.

The data are based on cases of 16 patients with GC hepatotoxicity with highly probable or probable causality levels reported in a publication [78]. Abbreviations: ALT, Alanine aminotransferase; AST, Aspartate aminotransferase; GC, Greater Celandine; HILI, Herb induced liver injury; PAs, Pyrrolizidine alkaloids; RUCAM, Roussel Uclaf Causality Assessment Method.

Another example is the hepatotoxicity by Indian Ayurvedic herbs (Table 4) [41]. This case represents again the idiosyncratic HILI type with its metabolic subtype. It is interesting to note that HILI by other Indian Ayurvedic herbs that are consumed not only in India but also worldwide are not commonly published in the English language, excepting perhaps herbs coantaining PAs. 
Table 4. Typical follow-up of symptoms in a case of HILI by Indian Ayurvedic herbs.

\begin{tabular}{ll}
\hline Conditions & Symptoms \\
\hline & $\begin{array}{l}\text { Well-being during first } 6 \text { months of treatment with } \\
\text { Indian Ayurvedic herbs for her vitiligo. }\end{array}$ \\
$\begin{array}{ll}\text { - Herbal use for overall } 9 \text { months, with full daily } \\
\text { dose as recommended for the initial 7 months. }\end{array}$ & $\begin{array}{l}\text { months, with subsequent symptoms step by step: Loss } \\
\text { of appetite, fatigue, nausea, and vomiting several times } \\
\text { per week. }\end{array}$ \\
\hline
\end{tabular}

- After herbal use for 7 months, dose reduction to $50 \%$ for the remaining 2 months of treatment. Dose reduction was the patient's decision. The clinic in India, which distributed this herbal medicine via internet, denied an association with the described symptoms.

Dark urine after use of herbs for 7 months. Reduced daily dose led to disappearance of pruritus but other symptoms persisted.

Light-colored stool as new symptom appearing 8 months after initiation of the herbal treatment.

- First presentation to her PCP 9 months after initiation of herbal treatment

- Discontinuation of herbal treatment 9 months after treatment initiation and 3 months following emerging pruritus as the first symptom

\author{
Jaundice was objectively confirmed
} Hospital admission the other day and discontinuation
of the herbal treatment as HILI was suspected. Clinical
evaluation with exclusion of alternative diagnoses
including HEV. Causality assessment by RUCAM that
provided a probable causality.
Following cessation of herbal treatment, clinical
symptoms and LTs rapidly improved to complete
recovery.
This case is best described as idiosyncratic HILI of the
metabolic type.

\begin{abstract}
Additional details are presented in a previous report [41]. Abbreviations: HEV, Hepatitis E Virus; HILI, Herb induced liver injury; PCP, Primary care provider; RUCAM, Roussel Uclaf Causality Assessment Method; LT,
\end{abstract} liver tests.

Kava hepatotoxicity is primarily an idiosyncratic liver injury of the metabolic subtype in most cases, but it may also have features of an intrinsic injury type (Table 5) [80,81]. This dualism of typology is the result of various analyses [80-93]. In most kava products, toxic ingredients were likely absent, and their hepatotoxicity is based on idiosyncrasy in few susceptible individuals (Table 5). In few other kava products, toxic ingredients presumably are present, causing intrinsic hepatotoxicity in those few individuals who took these products [80-93]. The overall rarity of kava hepatotoxicity was also considered in a recent court trial and evaluated as a positive constellation of benefit and risk [93], opposing previous regulatory assumptions to the contrary [94].

\title{
5.2.2. Intrinsic HILI Type
}

Some examples of typical intrinsic HILI are considered that are of major clinical or scientific interest. Among these are plants containing PAs such as Crotalaria species (Bush tea, Rattlebox), Gynura segetum, Ilex paraguarensis (Mate tea), Symphytum species (Comfrey), Senecio species (Groundsel), Heliotropium species, and Compositae species (Indian herbs) which cause HSOS as a specific form of liver damage [26-34,38]. Unsaturated PAs damage the sinusoid endothelial cells of the liver and reduce thereby the sinusoidal blood flow [38], which explains the typical clinical features of HSOS, caused for instance by Gynura segetum (Table 6) [28]. HSOS caused by unsaturated PAs is clearly dose dependent, thereby predictable, and hence preventable. Consequently, every consumer of these herbs containing PAs is at a dose dependent risk of HSOS. Plants containing PAs are among the most abundant poisonous plants affecting not only humans but also livestock and wildlife, with more than 6000 plant species containing PAs and about 3\% of the world's flowering plants containing PAs [95]. Human embryotoxicity by PAs resulting in fetal HSOS has been described in a newborn whose mother drank one cup of a tea containing PAs per day throughout pregnancy $[95,96]$. 
Table 5. Clinical characteristics of kava hepatotoxicity.

\begin{tabular}{|c|c|}
\hline Items & Clinical Characteristics of Kava Hepatotoxicity \\
\hline - Positive reexposure result & 1. The existence of kava hepatotoxicity has been verified by a positive reexposure test; \\
\hline - RUCAM & $\begin{array}{l}\text { 2. RUCAM based causality for kava } \pm \text { comedication was graded probable in } 4 \\
\text { patients; } \\
\text { 3. In nine patients and thus in the majority of case, causality for kava } \pm \text { comedication } \\
\text { was possible and hence weak; }\end{array}$ \\
\hline - Kava products & $\begin{array}{l}\text { 4. Kava hepatotoxicity may be caused by traditional aqueous kava extracts, } \\
\text { commercial ethanolic and acetonic kava extracts, and kava-herbs mixtures; }\end{array}$ \\
\hline - Risk factors & $\begin{array}{l}\text { 5. Daily overdose of kavalactones and prolonged treatment were common } \\
\text { phenomena in patients with kava hepatotoxicity and considered as risk factors, } \\
\text { although it occurred also with normal doses under recommended therapy duration } \\
\text { of } 3 \text { months or less; } \\
\text { 6. Synthetic or herbal drugs and dietary supplements including herbal ones were } \\
\text { comedicated with kava in the majority of cases and considered as risk factors; } \\
\text { 7. Additional risk factors included non-adherence to regulatory treatment } \\
\text { recommendations, but not extraction media or solubilizers, used for the } \\
\text { manufacturing of the kava drug; }\end{array}$ \\
\hline - Age and Gender & $\begin{array}{l}\text { 8. The ages of the } 14 \text { patients with a probable causality for kava } \pm \text { comedication or a } \\
\text { highly probable causality for kava ranged from } 14 \text { to } 60 \text { years, and the ratio of } \\
\text { females: males was } 6: 1 \text {; }\end{array}$ \\
\hline - Hepatocellular injury & $\begin{array}{l}\text { 9. High serum activities were found for ALT but not for ALP, suggesting a } \\
\text { hepatocellular injury type in kava hepatotoxicity; }\end{array}$ \\
\hline - Liver histology & 10. Histology showed predominantly liver cell necrosis and hepatitis; \\
\hline $\begin{array}{l}\text { Pathogenetic type of } \\
\text { liver injury }\end{array}$ & $\begin{array}{l}\text { 11. Depending on the kava product used, kava hepatotoxicity represents primarily } \\
\text { the idiosyncratic type of injury with the metabolic subtype but secondarily also the } \\
\text { intrinsic type of injury; the intrinsic and thereby predictable type of hepatotoxicity } \\
\text { applies to those patients who might have used one of the few extracts containing } \\
\text { kava of inappropriate quality with toxic properties, or who took kava with daily } \\
\text { overdose or prolonged; }\end{array}$ \\
\hline - Incidence & $\begin{array}{l}\text { 12. Valid epidemiology data are lacking, and the incidence of kava hepatotoxicity } \\
\text { cannot be accurately calculated, but appears to be low. }\end{array}$ \\
\hline
\end{tabular}

Data are derived from a previous report [80,81] and consider other analyses and publications [82-92]. Abbreviations: ALP, Alkaline phosphatase; ALT, Alanine aminotransferase; RUCAM, Roussel Uclaf Causality Assessment Method.

Table 6. Clinical characteristics of the hepatic sinusoidal obstructive syndrome (HSOS) caused by Gynura segetum containing unsaturated PAs.

\begin{tabular}{ll}
\hline Conditions & Results \\
\hline - Cohort & $n=116$ \\
- Gender & Males 57 \\
& Females 56 \\
- Age & (NA 3) \\
- Ascites & $17-76$ years \\
- Hepatomegaly & $115 / 116$ cases \\
- Jaundice & $104 / 113$ cases \\
- ALT elevation & $95 / 113$ cases \\
& $47 / 60$ cases \\
- AST elevation & (NA 56 cases) \\
& $50 / 58$ cases \\
- Outcome & (NA 58 cases) \\
& Recovery 75 cases \\
& Chronicity 27 cases \\
\hline
\end{tabular}

Data from Gao et al., 2012 [28]. Abbreviations: ALT, Alanine aminotransferase; AST, Aspartate aminotransferase; NA, Not available; PAs, Pyrrolizidine alkaloids.

Other intrinsic HILI are caused by plants such as Germander [72], Radix bupleuri [97,98], Polygonum multiflorum [99], and green tea extracts (GTE) [13,22-24,100]. Germander hepatotoxicity is dose 
dependent, well described in detail, and is reproducible in mice [72]. Herbal TCM products containing more than $19 \mathrm{~g}$ dose of Radix bupleuri may increase the hepatotoxicity risk [97]; this dose dependency was confirmed in experimental animals and provided insights into some pathogenetic processes [98]. Hepatotoxicity by Polygonum multiflorum is also a classic example of intrinsic HILI [99]. Finally, GTE also shows a clear dose dependency, classifying thereby GTE hepatotoxicity as intrinsic HILI $[13,22-24,100]$.

\section{Clinical Features of HILI}

PCP and clinicians are faced with the problem to identify patients with suspected HILI early in the evolving disease. However, clinical symptoms of patients with hepatotoxicity by herbal traditional and modern medicine are variable, mostly unspecific, and usually difficult to attribute to the liver, which delays early recognition of the unfolding liver injury [15,70]. In the context of clinical signs, two groups have to be differentiated, one group with HSOS by HILI from PA containing herbs and the other group with HILI unrelated to the use of PA containing herbs.

Patients with HSOS present with abdominal distension and pain, malaise and body weight gain due to hepatomegaly and ascites [29]. On a quantitative basis, typical clinical signs are shown as example for Gynura segetum causing HSOS (Table 6). The leading symptom of HSOS is ascites, which is otherwise rarely found in patients with HILI unrelated to PA use, except perhaps in end stage conditions. Ascites as the leading clinical sign must alert the physician considering HSOS as a diagnostic option. Discrediting this key finding has led in the past to abundant misdiagnoses and further harm to the patients, as detailed and discussed in many reports [25-34].

Other clinical signs prevail in patients with HILI unrelated to the use of PA containing herbs (Table 3-Table 5) because ascites is uncommon and not reported in HILI cases by GC [78], Indian Ayurvedic herbs [41], and kava [80,81] as well as Polygonum multiflorum [99], or other TCM herbs $[70,101]$. In detail, patients with herbal TCM hepatotoxicity experience fatigue (67.3\%), jaundice $(60.3 \%)$, anorexia $(58.0 \%)$, nausea $(35.9 \%)$, and fever $(19.3 \%)$, but signs such as rash, pruritus, and pale colored stools have also been reported [70]. In another study with established HILI by GC, symptoms were present in 15 of 16 reported cases [78]. Single or multiple symptoms were jaundice $(n=15)$, nausea $(n=6)$, fatigue $(n=5)$ anorexia $(n=3)$, dark urine $(n=3)$, pruritus $(n=3)$, vomiting $(n=2)$, dyspepsia $(n=1)$, bloating $(n=1)$, abdominal discomfort $(n=1)$, right upper quadrant pain $(n=1)$, epigastric pain $(n=1)$, unspecified abdominal pain $(n=1)$, pale stools $(n=1)$ and fever $(n=1)$ [78]. Patients with HILI may be asymptomatic with increased values observed by chance, mono-symptomatic, or poly-symptomatic, while jaundice is the best initially recognized symptom by the patient, facilitating the search for advice by the PCP [78]. In HILI cases unrelated to PAs, the chronology of symptoms commonly follows a particular stepwise pattern, as described for HILI caused by Indian Ayurvedic herbs, through an excellent observation by a patient (Table 4) [41]. Her symptoms started with pruritus, followed by loss of appetite, fatigue, nausea, vomiting, dark urine, light colored stools, until finally jaundice was recognized by her family physician; this sequence of symptoms stretched over almost four months under continued medication.

Latency periods defined as interval between start of herbal use and emerging symptoms or increased liver values are variable. Liver injury by herbal TCM develops slowly with clinical symptoms appearing between one week and one month [70], or up to 150 days [101]; with a longer latency period of four to 260 weeks for GTE [13,23], of one week to 24 months for other herbs such as kava [80,81], of 28 to 134 days for GC [78,79], or of seven months for Indian Ayurveda herbs [41].

\section{Progress in Developing Valid Diagnostic Biomarkers}

Numerous serologic markers exist, that enable a firm diagnosis of most liver diseases unrelated to HILI and DILI, for instance by assessing specific antibodies of viral hepatitis. New encouraging steps with the development of specific biomarkers for HILI are discussed [71] in reference to a sensitive and specific assay enabling the detection of reactive pyrrole-protein adducts in the serum of patients 
with HSOS. This disease was attributed to the Tusanqi preparation made erroneously with Gynura segetum containing PAs instead with Segetum aizoon lacking PAs [26]. The results of this assay show that the patient actually consumed a herb containing PAs, which are metabolized in the liver to a reactive PA metabolite, reacting with a protein and forming an adduct [71]. However, this assay does not prove that PAs have caused the hepatotoxicity in this particular patient, as supportive evidence is required in the clinical context. Measuring herbal toxins or their metabolites in the serum is useful in HILI cases in a setting of intoxication, if high levels of the herbal toxin are expected in the serum due to large amounts of the consumed herb, high cumulative doses, or a prolonged degradation of the toxic herbal chemical. These conditions apply to HILI cases of the intrinsic form but not to those of the idiosyncratic form, which accounts for most HILI cases. For idiosyncratic HILI, similar restrictions apply regarding circulating micro-RNA (mRNA), presently investigated in intrinsic DILI and detectable in fluids including the serum [102]. Omics technologies, including genomics, proteomics, and metabolomics might well change but not revolutionize our understanding in the diagnosis of intrinsic hepatotoxicity [103].

For idiosyncratic DILI, numerous genetic and nongenetic risk factors have been described as possible biomarkers to predict DILI in susceptible individuals [104], but whether these are useful to identify a person at risk for idiosyncratic HILI is unknown.

\section{HILI Case Criteria}

A case of acute HILI is defined by increased serum levels of ALT (alanine aminotransferase) of at least $5 \mathrm{~N}$ and/or of ALP (alkaline phosphatase) of at least $2 \mathrm{~N}$, whereby $\mathrm{N}$ represents the upper limit of normal [12]. Both tests should be best performed simultaneously on the day of first presentation or suspicion. These thresholds were chosen to increase the specificity of causality assessment for hepatotoxicity, eliminate false positive cases, and substantiate hepatotoxicity causality with a high level of probability. Special care is needed, if ALT is within the normal range and ALP is increased, this should then be paralleled by increased $\gamma$-glutamyltranspeptidase or better $5^{\prime}$-nucleosidase to rule out isolated increase of ALP activity due to bone or another origin than hepatobiliary disease [12].

\section{Liver Injury versus Adaptation}

Hepatotoxicity criteria are to be applied for each case of suspected HILI [12]. Concern emerges whenever hepatotoxicity is suspected even if LTs were only marginally increased, not reported, or not available. These problems are common for cases of suspected HILI, presented for instance by the United States Pharmacopeia [105] relating to both black cohosh (BC) [106-110] and GTE [24,111], by the World Health Organization relating to kava [88,112], by the German regulatory agency BfArM (Bundesinstitut für Arzneimittel und Medizinprodukte) $[94,113]$ relating to kava $[81,114]$, or by the Drug Commission of the German Medical Association [115] relating to Pelargonium sidoides (PS) [116-118]. In contrast, published case reports receive the benefit of appropriate peer reviews, and thus the presented HILI cases provide relevant data, commonly reporting high values of aminotransferases and/or ALP and basic data support of potential hepatotoxicity, as shown also for some cases with a positive reexposure test [119]. In other HILI case series, however, criteria were documented incompletely; neglecting these aspects in effect invalidates the causality assessment.

Contrasting to severe liver injury with its high LTs [47], use of herbal TCM may also cause only mild LT increases [120] that remain below the threshold values of liver injury [12]. These conditions are considered as liver adaptation or tolerance, especially if herbal use is continued and LTs remain stable or return to normal range, but transition to severe liver injury is possible. Liver adaptation is commonly observed under a therapy with synthetic drugs such as statins and antituberculous medications, especially isoniazid, and is likely the consequence of metabolic events during enzymatic drug degradation [121]. Most herbal products are well tolerated by the majority of consumers [6]. Even under comedication with synthetic drugs, only slight increases of LTs are rarely observed in 
patients under treatment with herbal TCM; in some of these patients, pre-existing LT abnormalities were known but were obviously not considered as risk factors of HILI by herbal TCM [120].

\section{HILI Case Classification}

For cases of suspected HILI, hepatotoxicity case classification is mandatory to facilitate further evaluation of reexposure results and RUCAM assessments [12]. The classification of the liver injury pattern (also called phenotype) is essential and must be provided. Three different types of liver injury are to be considered: hepatocellular, cholestatic, and mixed. These types can readily be identified by initial measurement of ALT and ALP without the need of a liver biopsy result [12]. The ratio $R$ is the basis for the classification and is calculated as the ALT: ALP, both activities measured at the time when liver injury is suspected and expressed as multiples of $\mathrm{N}$, the upper limit of the normal range. Liver injury is hepatocellular if $R \geqslant 5$; liver injury is cholestatic if $R \leqslant 2$; and liver injury is mixed if $2<R<5$. This classification of liver injury pattern clearly assigns each HILI case to RUCAM (Roussel Uclaf Causality Assessment Method), either for the hepatocellular injury, the cholestatic, or the mixed liver injury.

In a HILI case series of herbal TCM consisting of 27 patients, the pattern of liver injury was hepatocellular in $82 \%$ of the cases, cholestatic in $11 \%$, and mixed in $7 \%$ [101]. In another small case series of HILI by herbal TCM, all 12 patients who experienced an unintentional reexposure had a hepatocellular type of injury [47].

\section{RUCAM as the Most Used Method to Assess Causality}

Causality for herbs in patients with suspected HILI is best achieved with RUCAM in its current version updated in 2016, which provides two scales, one for the hepatocellular type of injury and the other one for the cholestatic or mixed type of liver injury [12]. RUCAM is a well established tool to quantitatively assess causality in HILI and DILI cases (Table 7) and has many advantages compared to other causality tools, as discussed in detail in reference to other approaches that cannot substitute RUCAM [12]. Representing a structured, standardized, and validated diagnostic approach specific for hepatotoxicity, RUCAM attributes scores to individual key items that reflect the natural course of HILI. The scores provide a final quantitative grading of causality for each suspect herb in a case report (range of final scores from 14 to -3 ) of highly probable, probable, possible, unlikely, or excluded. This meets the requirements of clinicians in care for their patients with suspected HILI, to establish the diagnosis in time with a high degree of confidence. In many countries and for more than two decades, physicians, international registries, regulatory agencies, and pharmaceutical companies successfully applied RUCAM for suspected HILI, and the score is also used in case reports with increasing tendency [12].

RUCAM covers a broad spectrum of alternative diagnoses that must be excluded before HILI can be assumed as cause of liver damage: these include infections by various hepatotropic viruses, not limited to hepatitis A, hepatitis B, hepatitis $C$ and hepatitis $E$ virus (HEV) with specific parameters [12]. Equally important for RUCAM are infections by cytomegalovirus, Ebstein Barr virus, herpes simplex virus and varizella zoster virus, to be assessed by parameters such as PCR and IgM/IgG antibody titers also upon repetitive testing. RUCAM also pays special attention to HEV, a neglected infection in assessments of liver injury cases [48-50,122-125]. Even in a clinical trial, an infection by HEV may occur and create confusion, mimicking a DILI [126]. An additional problem exists in the United States, where the HEV issue remains disputed due to lack of FDA-approved HEV antibody tests that provide valid results $[49,50,123,124]$. These viral infections being the causes of pre-existing liver diseases need to be excluded in the diagnostic approach of HILI.

Overall, assessment with RUCAM provides transparency by presenting each RUCAM item with the appropriate score, which should be included in published cases to facilitate reassessment and discussions among experts [12]. RUCAM is user-friendly as it highlights possible differential diagnoses, so that the work-up of an individual patient can be achieved in the absence of a hepatology specialist. 
Table 7. Core elements and advantages of RUCAM.

\begin{tabular}{lc}
\hline Items & RUCAM \\
\hline - Time frame of latency period (score) & + \\
- Time frame of dechallenge (score) & + \\
- Recurrent ALT or ALP increase (score) & + \\
- Definition of risk factors (score) & + \\
- All comedications (score) & + \\
- Individual comedication (score) & + \\
- Search for individual alternative causes (score) & + \\
- Verified exclusion of specific alternative causes (score) & + \\
- All specifically assessed HAV, HBV, HCV, HEV (score) & + \\
- All specifically assessed CMV, EBV, HSV, VZV (score) & + \\
- Evaluation of cardiac hepatopathy (score) & + \\
- Liver and biliary tract imaging (score) & + \\
- Color Doppler sonography of liver vessels (score) & + \\
- Prior known hepatotoxicity (score) & + \\
- Search for unintended reexposure (score) & + \\
- Definition of unintended reexposure (score) & + \\
- Qualified criteria of unintended reexposure (score) & + \\
- Laboratory hepatotoxicity criteria & + \\
- Laboratory hepatotoxicity pattern & + \\
- Hepatotoxicity specific method & + \\
- Structured, liver related method & + \\
- Quantitative, liver related method & + \\
- Validated method (gold standard) & + \\
- Worlwide use & + \\
- Use by international registries & + \\
- Use by regulatory agencies & + \\
- Use by HILI case reports & + \\
- Use by HILI case series & + \\
- Transparent documentation & + \\
\hline & + \\
\hline & + \\
\hline
\end{tabular}

Data are adapted from a previous report [12]. Abbreviations: ALT, Alanine aminotransferase; ALP, Alkaline phosphatase; CMV, Cytomegalovirus; EBV, Epstein Barr Virus; HAV, Hepatitis A Virus; HBV, Hepatitis B Virus; HCV, Hepatitis C Virus; HEV, Hepatitis E Virus; HILI, Herb induced liver injury; HSV, Herpes simplex Virus; RUCAM, Roussel Uclaf Causality Assessment Method; VZV, Varicella zoster Virus.

An internationally harmonized, uniform approach of causality assessment is preferred, including a case narrative, RUCAM, and a checklist for differential diagnoses of HILI [12]; optionally, an expert panel may assist, reassessing the clinical case characteristics and the quantified RUCAM items obtained by the caring physician. This structured approach would help to ensure completeness und transparency of case data. It is also a chance for an internationally harmonized approach of causality assessment and improves the acceptance of published case reports or case series on HILI. It would be helpful if uniformity of HILI criteria including specific scoring was established worldwide so published data across countries, and their registries could be harmonized and easily interpreted across populations. Therefore, RUCAM should best be considered as a standardized approach for causality assessment of HILI cases, both for the attending physician and all later stages by experts if really needed [12]. Use of a single assessment method allows valid and reproducible comparisons of different assessment outcomes.

RUCAM also provides clear criteria for a positive unintentional reexposure [12]. Such positive result is considered a gold standard to establish the DILI diagnosis; this was also used to validate RUCAM as reliable diagnostic tool for causality assessment [127]. None of the other causality assessing methods such as the DILIN method, the WHO method, or the Naranjo scale used any gold standard for validation, and the two latter assessing approaches are not hepatotoxicity specific and hence obsolete [12]. 


\section{Reexposure}

Reexposure can only be involuntary since intentional reexposure is considered unethical due to the high risk of severe liver injury [12]. Although unintentional reexposure is rarely described in HILI cases, reported results are of utmost importance for individual case analysis, provided their results are positive and meet the required criteria (Table 8).

Table 8. Conditions of unintentional reexposure tests in HILI cases.

\begin{tabular}{lcccc}
\hline \multirow{2}{*}{ Reexposure Test Result } & \multicolumn{2}{l}{ Hepatocellular Injury } & \multicolumn{2}{c}{ Cholestatic or Mixed Liver Injury } \\
\cline { 2 - 5 } & \multicolumn{1}{c}{$\mathbf{A L T b}$} & $\mathbf{A L T r}$ & $\mathbf{A L P b}$ & $\mathbf{A L P r}$ \\
\hline - Positive & $<5 \mathrm{~N}$ & $\geqslant 2 \mathrm{ALTb}$ & $<2 \mathrm{~N}$ & $\geqslant 2 \mathrm{ALPb}$ \\
- Negative & $<5 \mathrm{~N}$ & $<2 \mathrm{ALTb}$ & $<2 \mathrm{~N}$ & $<2 \mathrm{ALPb}$ \\
- Negative & $\geqslant 5 \mathrm{~N}$ & $\geqslant 2 \mathrm{ALTb}$ & $\geqslant 2 \mathrm{~N}$ & $\geqslant 2 \mathrm{ALPb}$ \\
- Negative & $\geqslant 5 \mathrm{~N}$ & $<2 \mathrm{ALTb}$ & $\geqslant 2 \mathrm{~N}$ & $<2 \mathrm{ALPb}$ \\
- Uninterpretable & $<5 \mathrm{~N}$ & n.a. & $<2 \mathrm{~N}$ & n.a. \\
- Uninterpretable & n.a. & $\geqslant 2 \mathrm{ALTb}$ & n.a. & $\geqslant 2 \mathrm{ALTb}$ \\
- Uninterpretable & n.a. & n.a. & n.a. & n.a. \\
\hline
\end{tabular}

Conditions and criteria for an unintentional reexposure test are described in a previous report [12]. Accordingly, required data for the hepatocellular type of liver injury are the ALT levels just before reexposure, referred to as baseline ALT or ALTb, and the ALT levels during reexposure, referred to as ALTr. Response to reexposure is positive, if both criteria are met: first, ALTb is below $5 \mathrm{~N}$ with $\mathrm{N}$ as the upper limit of the normal value, and second, after reexposure, ALT should increase to at least twice the baseline ALT value (ALTr $\geqslant 2 A L T b$ ). Other variations are evaluated as negative or uninterpretable results. For the cholestatic ( \pm hepatocellular) type of liver injury, corresponding values of ALP are to be used instead of ALT. Abbreviations: ALP, Alkaline phosphatase; ALT, Alanine aminotransferase; HILI, Herb induced liver injury; N, Upper limit of Normal; n.a., not available.

In recent analyses of cases with HILI by herbal TCM, cases were compiled which underwent assessment by RUCAM, reexposure test, or both [128,129]. Positive reexposure test results ensured causality for only a few TCM herbs, for which HILI was described. For more herbs, a probable or highly probable causality grading by RUCAM was achieved and provided a clear causality of HILI. Regarding the reexposure tests, positive results are claimed in many case reports for individual TCM herbs, but criteria were not fulfilled, resulting in uninterpretable or even negative results [128,129]. For future cases, details of the essential criteria for positive test results should be provided to allow reevaluation.

\section{Herbs with Established Causality for HILI}

Some TCM herbs of this category are listed (Table 9), this also included green tea (La Chu) as its GTE $[13,23,100]$. For non-TCM herbs with established causality by RUCAM, positive reexposure test, or both, analyses were provided for GC (Table 3), kava (Table 5), Indian Ayurvedic herbs [41], Aloe, Chaparral, Germander, Mistletoe, Senna, and Skullcap [129]. Certainly many more herbal products will have to be added, awaiting further analyses. For this category but without providing criteria, proposals have been also made recently for Chaparral, Comfrey, Senna, and wild germander, in addition to the TCM He Shou Wu [9]. 
Table 9. Causality assessment by RUCAM and/or positive reexposure tests in cases with assumed herbal hepatotoxicity by Traditional Chinese Medicine (TCM).

\begin{tabular}{|c|c|c|}
\hline Herbal TCM & RUCAM Based Causality & Reexposure Based Causality \\
\hline - Bai Xian Pi & + & - \\
\hline - Bo He & + & - \\
\hline - Ci Wu Jia & + & - \\
\hline - Chuan Lian Zi & + & - \\
\hline - Da Huang & + & - \\
\hline - Gan Cao & + & - \\
\hline - Ge Gen & + & - \\
\hline - Ho Shou Wu & + & - \\
\hline - Huang Qin & - & - \\
\hline - Hwang Geun Cho & - & + \\
\hline - Ji Gu Cao & - & + \\
\hline - Ji Xue Cao & - & - \\
\hline - Jin Bu Huan & + & + \\
\hline - Jue Ming Zi & + & - \\
\hline - Jiguja & + & - \\
\hline - Kudzu & - & - \\
\hline - Ling Yang Qing Fei Keli & + & - \\
\hline - Lu Cha & + & + \\
\hline - Ma Huang & - & + \\
\hline - Polygonum multiflorum & + & + \\
\hline - Rhen Shen & + & - \\
\hline - Shou Wu Pian & + & + \\
\hline - Shan Chi & + & - \\
\hline - Shen Min & + & - \\
\hline - Syo Saiko To & + & + \\
\hline - Xiao Chai Hu Tang & - & + \\
\hline - Zexie & + & - \\
\hline - Zhen Chu Cao & + & - \\
\hline
\end{tabular}

\section{Questionable and Lacking Causality}

The herbal TCM Ba Jiao Lian (Dysosma pleianthum) cannot be considered as hepatotoxic herb because essential diagnostic hepatotoxicity criteria were lacking in patients who used this TCM herb $[47,130]$. In detail, after herbal use at recommended doses, the patients manifested abnormal liver function tests associated with nausea, vomiting, diarrhea, abdominal pain, thrombocytopenia, leucopenia, sensory ataxia, altered consciousness and persistent peripheral tingling or numbness. However, the increase of the aminotransferases was marginal, with preference of AST rather than ALT. The AST increase could reflect isolated damage of the mitochondria around the hepatic central vein or muscular damage, because of the associated increase of creatine phosphokinase, findings not in support for a clinically relevant toxic liver disease [47]. Clear evidence against a hepatotoxic potential was also provided for Jing Tian San Qi (Sedum aizoon) as another herbal TCM [47], based on the results of recent studies showing that in patients with HSOS, the hepatotoxic PAs in the herbal TCM Shan Chi (Gynura segetum) were responsible rather than the misidentified Sedum aizoon lacking these alkaloids [25-29,31]. RUCAM based causality was lacking for Pelargonium sidoides [116-118], OxyELITE Pro [48-50], and BC [106-110], for which a lack of hepatotoxicity was confirmed by meta-analysis of randomized controlled clinical trials [131]. 


\section{Alternative Diagnoses}

Analyses have shown that liver damage in suspected HILI can often be explained by alternative causes [48-50,132], a problem also reported for DILI cases [133]. The problem of missed diagnoses is multifaceted and caused by incomplete case data collection, poor case data analysis, incomplete transfer of case data from medical files to the manuscript, and unjustified upgrading of causality scores [48-50,132]. Clinical problems can emerge, when specific effective treatment and preventive measures that would have been available for some patients with alternative diagnoses are withheld [48-50]. The issue of alternative causes was assessed in 23 publications that comprised 573 cases of initially suspected HILI [132]. In this analysis, alternative diagnoses were evident in 278 cases (48.5\%) misdiagnosed as HILI. Among the missed diagnoses were hepatitis by various viruses $(9.7 \%)$, autoimmune liver diseases (10.4\%), nonalcoholic and alcoholic fatty liver disease (5.4\%), liver injury by comedication (DILI or other HILI) (43.9\%), and liver involvement in infectious diseases (4.7\%). Biliary and pancreatic diseases were frequent alternative diagnoses (11.5\%). Pre-existing liver diseases including cirrhosis (9.7\%) were additional confounders. Other diagnoses were rare, but possibly relevant for the individual patient [132]. These results are alarming, because HILI is by mainstream definition a diagnosis of exclusion, and it does not appear that this aspect was appropriately considered by some physicians. The use of RUCAM will certainly reduce the risk of missed diagnosis in future cases of suspected HILI [12].

As a reminder for the clinician that many diagnoses exist as alternatives to HILI, rare causes of liver disease are included in a checklist of differential diagnoses [12] These other diagnoses have to be considered, excluded or verified in the context of clinical data and importance, financial resources, and benefit for the patient. Establishing alternative causes contributes to the accuracy of RUCAM and often provides clues to possible specific therapies.

\section{Confounding Variables}

In the past, many case reports about HILI presented incomplete case data or neglected causal relation between suspected herbal compound and liver damage. As expected under these conditions, major shortcomings prevail that are to be considered as confounding variables impeding a valid causality in perhaps most of the reported cases (Table 10) [14,16,22,25-29,48-50,99,105-107,134,135]. For instance, chances were missed by a recent review article about HILI by Polygonum multiforme describing excellent details of the used herbal products, daily doses, and treatment duration among others; causality for the herb was not assessed and it remained unclear whether alternative causes were excluded (Table 10) [99]. Confounding variables may result in false high signal cases and case overreporting by overdiagnosing.

\section{Listing Compilation of Published Reports with Potentially Hepatotoxic Herbs}

Numerous case reports and case series have been published, suggesting that TCM herbs may have caused liver injury but results of a valid causality assessment were rarely provided. The presented listing compilation is therefore tentative and awaits further analyses including valid causality assessments such as by RUCAM for most of the published case reports and case serries (Table 11) [22-24,40,99,100,136-201]. Additional information and references for each herb under consideration is provided in two recent reports $[8,128]$. Another listing compilation is provided for non TCM herbs with reported and suspected liver injury (Table 12) $[22-24,32,40,41,72,100,111,136,137,149$, $158,171-178,180,189,202-311]$, which is adapted from a previous publication that provides additional data and references for each herb [8]. 
Table 10. Confounding variables as examples in case reports of HILI.

\begin{tabular}{|c|c|}
\hline $\begin{array}{l}\text { Problematic Items as Confounding Variables for } \\
\text { Causality Assessment in some Cases }\end{array}$ & $\begin{array}{l}\text { References for few HILI } \\
\text { Cases as Examples }\end{array}$ \\
\hline - Problematic plant authentication & {$[14,16,22,25-29,105-107]$} \\
\hline - Unspecified plant part & [107] \\
\hline - Lacking herbal product identification & {$[106,107]$} \\
\hline - Unidentified indication of herbal treatment & [107] \\
\hline - Unassessed daily dosage & [107] \\
\hline - Unidentified date of product start & [107] \\
\hline - Unidentified date of product stop & [107] \\
\hline - Unclear time to onset & {$[106,107]$} \\
\hline - Unconfirmed herbal product purchase & {$[49,50]$} \\
\hline - Unconfirmed herbal product use & {$[49,50]$} \\
\hline - Unassessed comedication by drugs & {$[48-50]$} \\
\hline - Use of many herbal dietary supplements & {$[49,50,107]$} \\
\hline - Unreported initial ALT value & [107] \\
\hline - Unreported initial ALP value & {$[107,135]$} \\
\hline - Unconsidered HAV & {$[50,107,135]$} \\
\hline - Unconsidered HBV & {$[50,99,106,107,135]$} \\
\hline - Unconsidered HCV & {$[50,99,106,107,135]$} \\
\hline - Unconsidered HEV & {$[48-50,99,106,107]$} \\
\hline - Unconsidered CMV & {$[50,99,106,107]$} \\
\hline - Unconsidered EBV & {$[48-50,99,106,107]$} \\
\hline - Unconsidered HSV & {$[48-50,99,106,107]$} \\
\hline - Unconsidered VZV & {$[50,99,106,107]$} \\
\hline - Incomplete imaging data & {$[99,106,107]$} \\
\hline - Ignored hepatotoxicity criteria & [107] \\
\hline - Causality assessment by non-RUCAM & {$[24,94,99,105,107,112,120]$} \\
\hline
\end{tabular}

Table 11. Listing compilation of TCM herbs and herbal products with reported hepatotoxicity.

\begin{tabular}{|c|c|}
\hline Chinese Name & Botanical Names, Ingredients \\
\hline - Ai Ye & Artemisia argyi \\
\hline - An Shu Ling & $\begin{array}{l}\text { Lycopodium serratum or rarely, Corydalis species, Panax ginseng, Pseudo ginseng, or two } \\
\text { species of Stephania }\end{array}$ \\
\hline - Bai Fang & $\begin{array}{l}\text { Angelica sinensis, Cyperus rotundus, Ginseng, Ligusticum wallichii, Paeonia alba, Rehmannia } \\
\text { glutinosa }\end{array}$ \\
\hline - Bai Shi Wan & $\begin{array}{l}\text { Atractylis, Carthamus tinctorius, Dalbergia odorifera, Dioscorea bulbifera, Glycyrrhiza, } \\
\text { Lithospermum erythrorhizon, Paeonia suffruticosa, Polygonum multiflorum, Psoralea corylifolia, } \\
\text { Salvia miltiorrhiza; Endoconcha sepiae, Ganoderma lucidum (mushroom) }\end{array}$ \\
\hline - Bi Ma Zi & $\begin{array}{l}\text { Rhicinus communis, Chaenomeles, Codonopsis pilosula, Notopterygium, Polygonum multiflorum, } \\
\text { Rehmannia, Schisandra }\end{array}$ \\
\hline - Bo He & Mentha haplocalyx \\
\hline - Bo Ye Qing Niu Dan & Tinospora crispa \\
\hline
\end{tabular}


Table 11. Cont.

\begin{tabular}{|c|c|}
\hline Chinese Name & Botanical Names, Ingredients \\
\hline - Bofu Tsu Sho San & $\begin{array}{l}\text { Angelica, Atractylis, Cnidium, Gardenia, Ephedra, Forsythia, Glycyrrhhiza, Gypsum fibrosum, } \\
\text { Ledebouriella, Mentha, Paeonia, Platycodon, Rheum, Schizonepeta, Scutellaria, Zingiber; Kadinum } \\
\text { (talcum powder), sodium sulfuricum }\end{array}$ \\
\hline - Boh Gol Zhee & Psoralea corylifolia \\
\hline - Cang Er Zi & Xanthium sibiricum \\
\hline - Chang Shan & Dichora febrifuga Lour \\
\hline - Chai Hu & Bupleurum falcatum \\
\hline - Chaso & Camellia sinensis, Cassia tora (syn. Senna), Crataegus, N-nitroso-fenfluramine \\
\hline - Chi R Yun & Breynia officinalis \\
\hline $\begin{array}{l}\text { - Chinese herbal } \\
\text { mixtures (various) }\end{array}$ & $\begin{array}{l}\text { Dictamnus dasycarpus, Gentiana scabra, Hedyotis diffusa, Paeonia suffructicosa, Paris polyphylla, } \\
\text { Rehmannia glutinosa, Smilax glabra, Sophora subprostrata; Angelica sinensis, Bupleurum chinese, } \\
\text { Dictamnus dasycarpus, Paeonia suffructiosa, Philodendron chinese, Saposhnikovia divaricata,Shisandra } \\
\text { chinesis, Shizonepeta tenuifolia, Tribulus terrestris; Cocculus trilobus, Dictamnus dasycarpus, Eurysolen } \\
\text { gracilis, Glycyrrhiza, Lophatherum, Paeonia, Potentilla, Rehmannia glutinosa; Alisma plantago aquatica, } \\
\text { Artemisia capillaris, Bupleurum, Chrysanthemum morifolium, Circuma, Gardenia jasminoidis, Gentiana } \\
\text { scabra, Glycyrrhiza, Magnolia, Paeonia, Plantago asiatica, Saussurea lappa }\end{array}$ \\
\hline - Chuan Lian Zi & Melia toosendan \\
\hline - Ci Wu Jia & Acanthopanax senticosus \\
\hline - Da Chai Hu Tang & $\begin{array}{l}\text { Bupleurum falcatum, Ginseng, Glycyrrhiza glabra, Pinellia, Scutellaria, Zingiber officinale, Zizyphus } \\
\text { jujuba }\end{array}$ \\
\hline - Da Huang & Rheum palmatum \\
\hline - Du Huo & Angelica archangelica \\
\hline $\begin{array}{l}\text { - Fu Fang Qing Dai } \\
\text { Wan }\end{array}$ & $\begin{array}{l}\text { Angelica dahurica, Isatis indigotica (Indigo naturalis), Massa medicata fermentata (yeast), Salvia } \\
\text { milthiorrhiza, Smilax glabra }\end{array}$ \\
\hline - Gan Cao & Glycyrrhiza uralensis, syn. Liquorice \\
\hline - Ge Gen & Pueraria lobata, syn. Arrowroot \\
\hline - He Huan Pi & Albizia julibrissin \\
\hline - Ho Shou Wu & Polygonum multiflorum, syn. He Shou Wu \\
\hline - Hu Bohe You & Mentha pulegium, syn. Pennyroyal oil \\
\hline - Hu Zhang & Polygonum cuspidatum \\
\hline - Huang Qin & Scutellaria baicalensis \\
\hline - Huang Yao Zi & Dioscorea bulbifera \\
\hline - Hwang Geun Cho & Corydalis speciosa \\
\hline - Ji Gu Cao & Abrus cantoniensis \\
\hline - Ji Ji & Chloranthus serratus \\
\hline - Ji Xue Cao & Centella asiatica, syn. Gotu Kola \\
\hline - Jiguja & Hovenia dulcis \\
\hline - Jin Bu Huan & $\begin{array}{l}\text { Lycopodium serratum or rarely, Corydalis species, Panax ginseng, Pseudo ginseng, or two species of } \\
\text { Stephania }\end{array}$ \\
\hline - Jue Ming Zi & Cassia obtusifolia, syn. Senna \\
\hline - Kamishoyosan & $\begin{array}{l}\text { Angelica sinensis, Atractylodes racea, Bupleurum falcatum, Gardenia, Glycyrrhiza glabra, Mentha } \\
\text { haplocalyx, Moutan, Paeonia alba, Sclerotium Poriae Cocos, Zingiber officinale }\end{array}$ \\
\hline - Kudzu & Pueraria thunbergiana \\
\hline - Ku Lian Zi & Melia azedarach \\
\hline - Lei Gong Teng & Tripterygium wilfordii Hook \\
\hline $\begin{array}{l}\text { - Long Dan Xie Gan } \\
\text { Tang }\end{array}$ & $\begin{array}{l}\text { Acebia, Alisma, Angelica sinensis, Bupleurum, Gardenia, Gentiana, Glycyrrhiza, Plantago, Rehmannia, } \\
\text { Scutellaria }\end{array}$ \\
\hline - Lu Cha & Camellia sinensis, syn. Chinese green tea \\
\hline - Ma Huang & Ephedra sinica \\
\hline - Mao Guo Tian Jie Cai & Heliotropium lasiocarpum \\
\hline - Onshido & $\begin{array}{l}\text { Aloe, Camellia sinensis, Crataegus, Gynostemma pentaphyllum makino, Raphanus; } \\
\text { N-nitroso-fenfluramine }\end{array}$ \\
\hline - Qian Li Guang & Senecio scandens \\
\hline - Ren Shen & Panax ginseng \\
\hline - Sairei To & $\begin{array}{l}\text { Alisma, Atractylis, Bupleurum, Cinnamomum, Ginseng, Glycyrrhiza, Pinellia, Polyporus, Poria, } \\
\text { Scutellaria, Zingiber, Zizyphus }\end{array}$ \\
\hline - Shan Chi & Gynura segetum \\
\hline - Shang Lu & Phytolacca acinosa \\
\hline - Shen Min & $\begin{array}{l}\text { Black cohosh, Burdock, Cayenne pepper, Ginkgo biloba, Horse chestnut, Piper nigrum, Polygonum } \\
\text { multiflorum, uva ursi; biotin, collagen (hydrolyzed), niacin, pantothenic acid, silica (from plant } \\
\text { sources), soy isoflavones, vitamin A, vitamin } \mathrm{B}_{6}\end{array}$ \\
\hline - Shi Can & Teucrium chamaedrys, syn. Germander \\
\hline - Shi Liu Pi & Pericarpium granati \\
\hline - ShouWu Pian & $\begin{array}{l}\text { Achyranthes bidentata, Cuscuta chinensis, Eclipta prostrata, Ligustrum lucidum, Lonicera japonica, } \\
\text { Morus alba, Polygonum multiflorum, Psoralea corylifolia, Rehmannia glutinosa, Rosa aevigat, Sesemum } \\
\text { indicum, Siegesbeckia orientalis }\end{array}$ \\
\hline - Tian Hua Fen & Trichosanthes kirilowii \\
\hline
\end{tabular}


Table 11. Cont.

\begin{tabular}{|c|c|}
\hline Chinese Name & Botanical Names, Ingredients \\
\hline - White flood & $\begin{array}{l}\text { Qian Ceng Ta (Huperzia serrata), Wu Zhu Yu Evodia rutaecarpa); beet root, caffein, cocoa bean, } \\
\text { vinpocetine (from Vinca plant); acesulfame potassium, calcium silicate, carnitine tartrate, } \\
\text { Carno-Syn }{ }^{\circledR} \text { beta-alanine, citrulline, cryptoxanthin, folic acid, gamma-aminobutyric acid (GABA), } \\
\text { glucuronolactone, selenium, L-norvaline, L-tyrosine, lutein, malic acid, ornithine, potassium } \\
\text { gluconate, sucralose, sugar cane, watermelon flavor, zeaxanthin }\end{array}$ \\
\hline - Wu Bei Zi & Galla chinensis \\
\hline - Xi Shu & Camptotheca acuminata \\
\hline - Xian Si Zi & Abrus Precatorius \\
\hline - Xiao Chai Hu Tang & $\begin{array}{l}\text { Bupleurum falcatum, Ginseng, Glycyrrhiza glabra, Pinellia tuber, Scutellaria baicalensis, Zingiber } \\
\text { officinale, Zizyphus jujuba }\end{array}$ \\
\hline - Yin Chen Hao & Artemisia capillaris \\
\hline - Zexie & Alisma orientalis \\
\hline - Zhen Chu Cao & Phyllanthus urinaria \\
\hline
\end{tabular}

Table 12. Listing compilation of herbs and herbal products with reported hepatotoxicity.

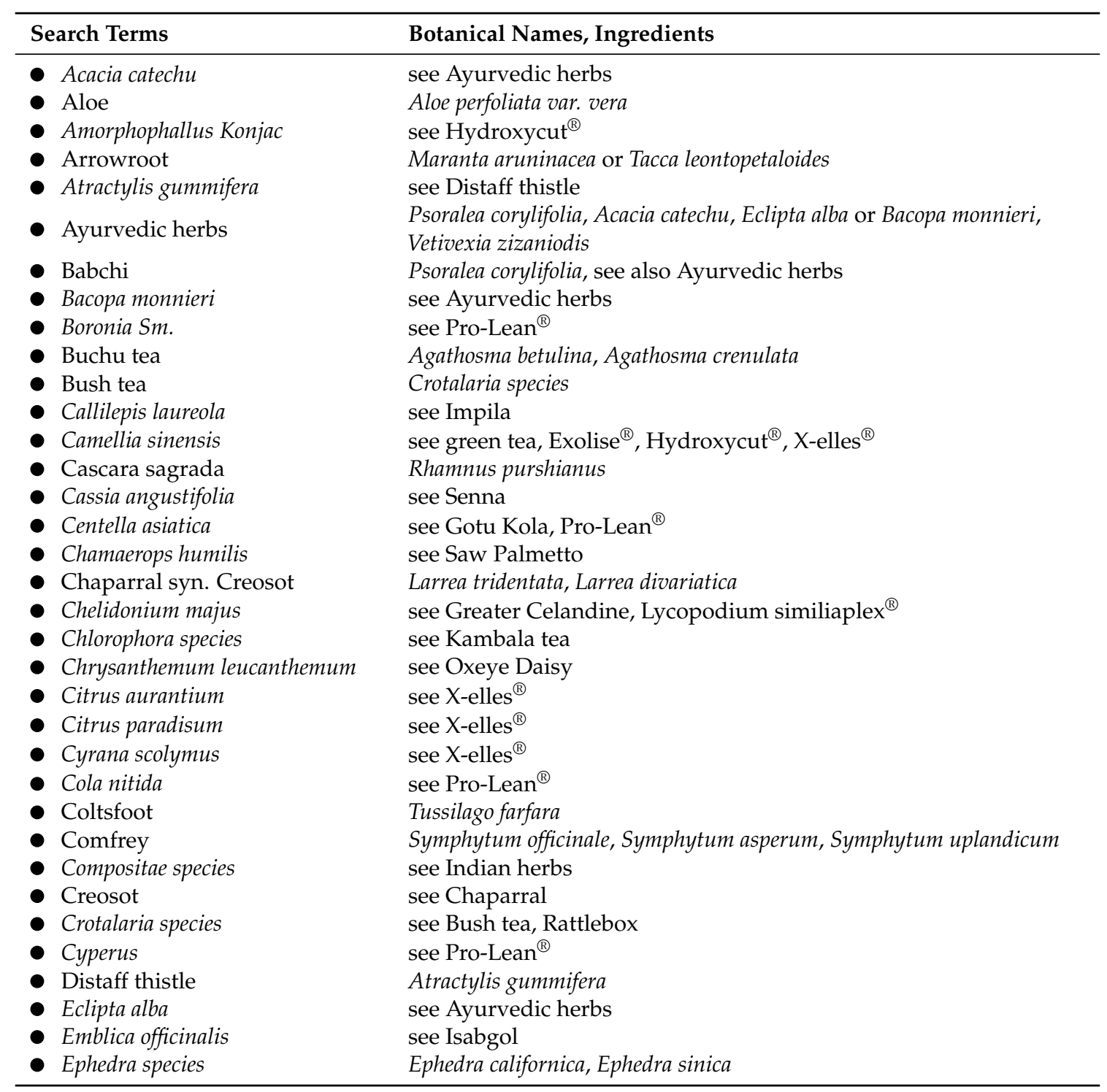


Table 12. Cont.

\begin{tabular}{|c|c|}
\hline Search terms & Botanical names, ingredients \\
\hline - Exolise ${ }^{\circledR}$ & $\begin{array}{l}\text { Garcinia cambogia, Gymnema sylvestre, White kidney bean, Camellia } \\
\text { sinensis, L-Carnitine fumarate, Calcium, Magnesium chelate, }\end{array}$ \\
\hline & Chromium chelate, Conjugated linoleic acid, Chitosan \\
\hline - Fallopia multiflora & see Pro-Lean ${ }^{\circledR}$ \\
\hline - Foeniculum amare & see Herbalife ${ }^{\circledR}$ \\
\hline - Fucus vesiculosus & see Pro-Lean ${ }^{\circledR}$ \\
\hline - Garcinia cambogia & see Exilis ${ }^{\circledR}$, Herbalife ${ }^{\circledR}$, Hydroxycut ${ }^{\circledR}$ \\
\hline - Germander & Teucrium chamaedrys, Teucrium polium \\
\hline - Ginkgo biloba & seePro-Lean ${ }^{\circledR}$ \\
\hline - Ginseng & see Bai Fang, Dai Saiko To, Pro-Lean ${ }^{\circledR}$, Xiao Chai Hu Tang \\
\hline - Glycyrrhiza glabra & See Dai Saiko To, Xiao Chai Hu Tang \\
\hline - Gotu Kola & Centella asiatica \\
\hline - Greater Celandine & Chelidonium majus, see also Lycopodium similiaplex ${ }^{\circledR}$ \\
\hline - Green tea & Camellia sinensis, see also Lu Cha \\
\hline - Groundsel syn. Senecio & Senecio longilobus, Senecio species \\
\hline - Guaraná & Paullinia cupana \\
\hline - Gymnema sylvestre & see Exilis ${ }^{\circledR}$, Hydroxycut ${ }^{\circledR}$ \\
\hline - Hawthorn & see Crataegus \\
\hline - Hedeoma pulegoides & see Pennyroyal \\
\hline - Heliotropium & Heliotropium eichwaldii, Heliotropium species \\
\hline - Herbalife ${ }^{\circledR}$ & $\begin{array}{l}\text { Solidaginis gigantea, Ilex paraguariensis, Petroselinum crispum, Garcinia } \\
\text { cambogia, Spiraea, Matricaria chamomilla, Liquiritia, Foeniculum amare, } \\
\text { Humulus lupulus, Chromium, and various other ingredients }\end{array}$ \\
\hline - Horse chestnut & see Venencapsan ${ }^{\circledR}$, Venoplant ${ }^{\circledR}$ \\
\hline - Humulus lupulus & see Herbalife ${ }^{\circledR}$ \\
\hline & Camellia sinensis, Gymnema sylvestre, Amorphophallus Konjac, Paullinia \\
\hline - Hydroxycut ${ }^{\circledR}$ & $\begin{array}{l}\text { cupana, Garcinia cambogia, Caffeine, } \alpha \text {-Lipoic acid, L-Carnitine, } \\
\text { Calcium, Potassium, Chromium }\end{array}$ \\
\hline - Ilex paraguariensis & see Herbalife ${ }^{\circledR}$, Maté \\
\hline - Impila & Callilepis laureola \\
\hline - Indian herbs & Compositae species \\
\hline - Iroko & see Kambala Tea \\
\hline - Isabgol & Plantago ovata, Emblica officinalis \\
\hline - Kambala Tea syn. Iroko & Chlorophora excelsa, Chlorophora regia \\
\hline - Kava & Piper methysticum \\
\hline - Larrea divariatica & see Chaparral \\
\hline - Larrea tridentata & see Chaparral \\
\hline - Leucanthemum vulgare & see Oxeye Daisy \\
\hline - Liquiritia & see Herbalife ${ }^{\circledR}$ \\
\hline - Lycopodium serratum & see Lycopodium similiaplex ${ }^{\circledR}$, Wolf's foot clubmass \\
\hline - Lycopodium similiaplex ${ }^{\circledR}$ & Lycopodium serratum, Chelidonium majus \\
\hline - Maranta aruninacea & see Arrowroot \\
\hline - Maté & Ilex paraguariensis \\
\hline - Mentha pulegium & see Pennyroyal \\
\hline - Mistletoe & Viscum album \\
\hline - Monascus purpureus & see Red Yeast Rice \\
\hline - Morinda citrifolium & see Noni \\
\hline - Nerium oleander & see Oleander \\
\hline - Noni & Morinda citrifolium \\
\hline - Oleander & Nerium oleander \\
\hline - Oxeye Daisy & Leucanthemum vulgare, Chrysanthemum leucanthemum \\
\hline - Paullinia cupana & see Guaraná, Hydroxycut ${ }^{\circledR}$, Pro-Lean ${ }^{\circledR}$ \\
\hline - Pennyroyal & Mentha pulegium, Hedeoma pulegoides \\
\hline - Petroselinum crispum & see Herbalife ${ }^{\circledR}$ \\
\hline
\end{tabular}


Table 12. Cont.

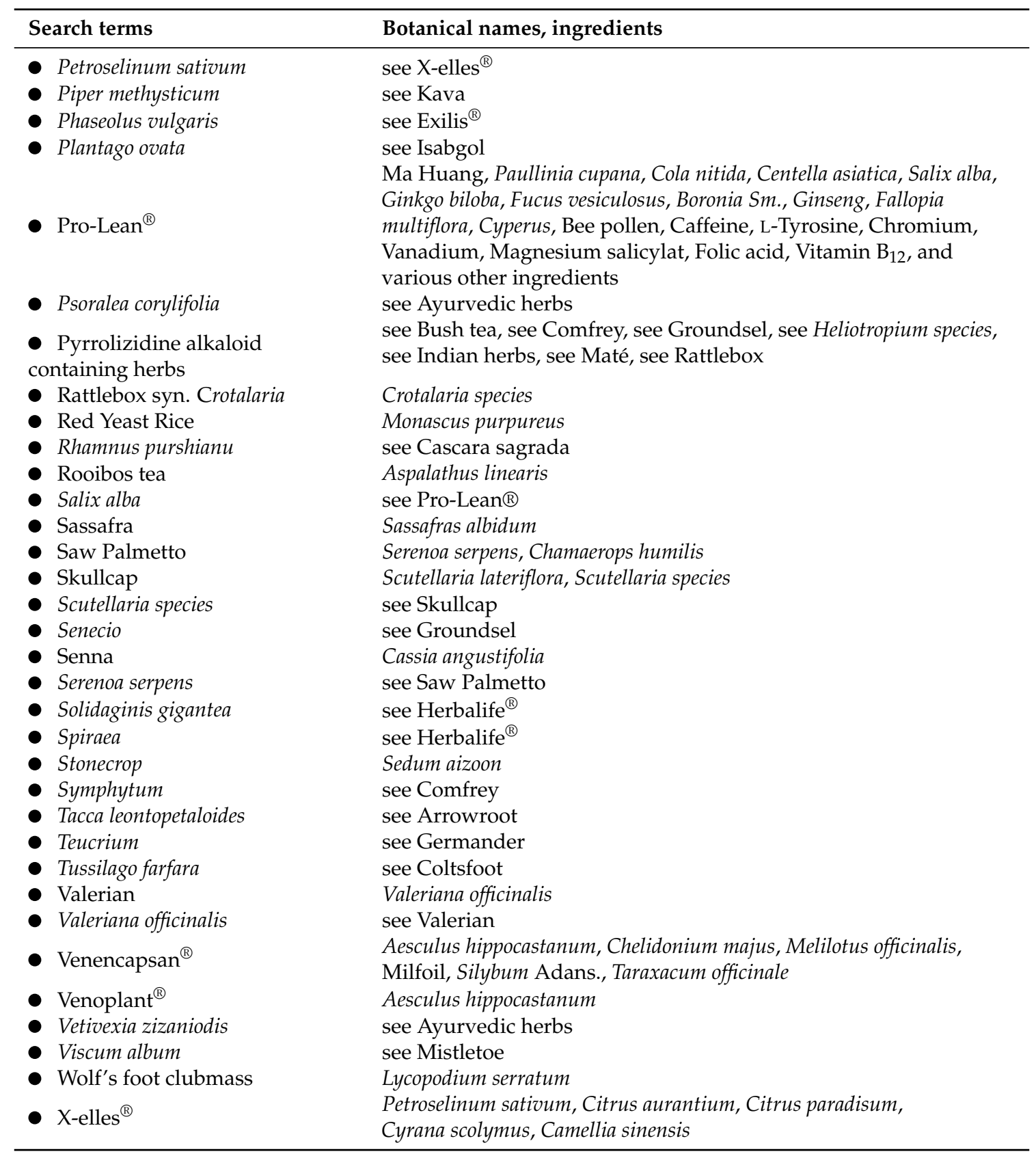

Data are collected from published reports [22-24,32,40,41,72,100,111,136,137,149,158,171,173-178,180,189,202-311], and specific references for each herb are found in a recent report [8]. For few of the herbs, causality was ascertained by using RUCAM or positive test results of unintentional reexposure. For most herbs, causality was not firmly established and is open for discussion.

\section{HILI Outcome and Management}

\subsection{Natural Course and Discontinuation of Herbal Use}

As expected, little firm information exists of the natural course of HILI under continued herbal use despite evident symptoms, with the exception of perhaps one single study reporting details of a HILI case series [78]. In this analysis, ignorance of symptoms with corresponding delay of therapy discontinuation was observed in patients with severe HILI by GC. This study cohort consisted of 16 patients with established RUCAM-based causality gradings of "probable" or "highly probable". In 15 of these patients $(93.8 \%)$, jaundice was the leading symptom [78], in line with a severe clinical course 
according to the criteria of Hy's law. Among the GC cohort patients, the accurate latency period to first symptoms was assessable in 13 patients; in eight of these, the latency period was identical with the duration of GC intake signifying that GC use was stopped after the appearance of first symptoms. In the remaining five cases with overt symptoms, treatment with GC was continued over a period of up to seven months but outcome was favorable, contrary to clinical expectations [78]. Such a good prognosis was not observed in a DILI case series in which the delayed cessation of the antituberculous drug was associated with a high risk of mortality [312]. Among 13 patients with continued isoniazid use for more than seven days, seven patients required a liver transplantation or died. Despite these differences of outcome depending on the offending product, intake of the herbal product must be stopped in cases of suspected HILI as a precautionary measure, especially since the efficacy of most herbal treatments has not validly been established by evidence based studies [7]. HILI commonly improves spontaneously upon cessation of the offending herb.

\subsection{Severe HILI and Hy's Law}

Severe clinical courses of HILI with acute liver failure (ALF) are extremely rare but may require orthotopic liver transplantation to circumvent a lethal outcome; the underlying risk factors are largely unknown [144]. Preventive measures are not available in these HILI cases that are caused likely by an idiosyncratic reaction in the majority of patients (Figure 1). Jaundice is one of the cardinal symptoms of severe HILI and likely associated with a high risk of lethality, at least in DILI [313] cases but not yet firmly determined in HILI. For quantitative risk management of HILI, helpful recommendations may be derived from Hy's law of the late Hyman Zimmerman, based on a 1 in 10 mortality risk of DILI if the following three criteria in short are met in hepatocellular liver injury: (1) serum ALT or AST $>3 N$; (2) serum total bilirubin elevated to $>2 \mathrm{~N}$; and (3) no other reason can be found for the combination of increased aminotransferases and bilirubin [313]. Patients with signs of impending acute liver failure (e.g., coagulopathy and encephalopathy) should be transferred to a specialized hepatology unit. Up to now, prognostic markers to predict the outcome and indicate, that a patient may require liver transplantation, are not evaluated in HILI.

\subsection{Adaptation}

Liver adaptation under herbal use requires LT surveillance [120]. This is mandatory due to the potential transition to severe injury. To be cautious, cessation of herbal use is recommended for the safety of the patients on a case by case basis, especially if indication is unclear and treatment was ineffective so far.

\section{HILI Outbreaks}

Several publications report HILI outbreaks related to consumption of food contaminated by plants, which contain unsaturated PAs [314-317]. For example, following a two-year period of severe drought, a very large number of patients with massive ascites and emaciation were observed in northwestern Afghanistan [314]. Clinico-pathological studies showed that these were typical cases of HSOS. The outbreak was caused by consumption of bread made from wheat contaminated with seeds of Heliotropium plants, which were shown to contain PAs. Examination of 7200 inhabitants from the affected villages showed evidence of liver disease in $22.8 \%$. Clinical improvement was observed in thirteen cases after three to nine months, and in three cases liver biopsies showed almost complete disappearance of initial abnormalities [314]. A more recent outbreak of HSOS was reported from Western Afghanistan, associated with exposure to wheat flour contaminated with PAs, but the incriminated plant remained unclear [315].

Two other outbreaks of HSOS were reported from India [316,317]. One of these was probably caused by consumption of cereals mixed with seeds of a plant (Crotalaria sp.) containing PAs, which occurred in the Sarguja district of India end of 1976; among the 67 recorded cases, $42 \%$ of the patients died [317]. 


\section{Regulatory Issues}

Consumers are confronted with abundant herbal products, encompassing herbal drugs and herbal dietary supplements, not all of which are under tight control by government regulatory agencies. Most of these products are likely safe, others are certainly not. Based on careful randomized controlled trials, a favorable benefit-risk profile has been shown only for a limited number of these products, including Artemisia annua with its ingredient artemisinin used to efficiently treat patients with malaria. Interestingly, alone in the United States, more than 50,000 dietary supplements were marketed between 1995 and 2015 [11]. This calls for some product restriction. Preference should be given to herbal products that are to be used as herbal medicines or herbal drugs and fulfill global regulatory requirements of efficacy and safety.

\section{Conclusions}

Herbal use is highly appreciated around the world to treat various health conditions. Many herbal products are easily accessible via the internet and thus can escape regulatory surveillance. Concomitantly, herb induced liver injury emerges as a clinical problem and can evolve into acute liver failure in rare cases. Clinical signs are often non-specific and there is no diagnostic feature that delineates HILI from alternative causes of liver damage. Therefore, the diagnosis of HILI is one of exclusion and the RUCAM score can aid the clinician to establish causality. Furthermore, assessment according to RUCAM facilitates evaluation of published cases and provides useful information for authorities to regulate the marketing of herbal products. Clinical studies to evaluate the benefit/risk balance of herbal drugs are encouraged. Finally, all herbal products and herbal dietary supplements used as medicine should be under a more strict regulatory surveillance, considering these products as herbal drugs.

Conflicts of Interest: The authors declare no conflict of interest.

\section{References}

1. Tu, Y.; Ni, M.Y.; Zhong, Y.R.; Li, L.N.; Cui, S.L.; Zhang, M.Q.; Qang, W.Z.; Hi, Z.; Li, X.T. Studies on the constituents of Artemisia annua Part II. Planta Medica 1982, 44, 143-145.

2. Tu, Y. The development of new antimalarial drugs: Qinghaosu and dihydro-qinghaosu. Chin. Med. J. 1999, 112, 976-977.

3. Efferth, T.; Romero, M.R.; Wolf, D.G.; Stamminger, T.; Marin, J.J.G.; Marschall, M. The antiviral activities of artemisinin and artesunate. Clin. Infect. Dis. 2008, 47, 804-808. [CrossRef] [PubMed]

4. Maridass, M.; de Britto, A.J. Origin of plant derived medicines. Ethnobot Leaflets 2008, 12, 373-387.

5. Pelkonen, O.; Xu, O.; Fan, T.P. Why is research on herbal medicinal products important and how can we improve quality? J. Tradit. Complement. Med. 2014, 4, 1-7. [CrossRef] [PubMed]

6. Ekor, M. The growing use of herbal medicines: Issues relating to adverse reactions and challenges in monitoring safety. Front. Pharmacol. 2014, 4, 1-10. [CrossRef] [PubMed]

7. Teschke, R.; Wolff, A.; Frenzel, C.; Eickhoff, A.; Schulze, J. Herbal traditional Chinese medicine and its evidence base in gastrointestinal disorders. World J. Gastroenterol. 2015, 21, 4466-4490. [PubMed]

8. Teschke, R.; Eickhoff, A. Herbal hepatotoxicity in traditional and modern medicine: Actual key issues and new encouraging steps. Front. Pharmacol. 2015, 6, 72. [CrossRef] [PubMed]

9. Calitz, C.; du Plessis, L.; Gouws, C.; Steyn, D.; Steenekamp, J.; Muller, C.; Hamman, S. Herbal hepatotoxicity: Current status, examples, and challenges. Expert Opin. Drug Metab. Toxicol. 2015, 11, 1551-1565. [CrossRef] [PubMed]

10. Zhao, P.; Wang, C.; Liu, W.; Chen, G.; Liu, X.; Wang, X.; Wang, B.; Yu, L.; Sun, Y.; Liang, X.; et al. Causes and outcomes of acute liver failure in China. PLoS ONE 2013, 8, e80991. [CrossRef] [PubMed]

11. Avigan, M.I.; Mozersky, R.P.; Seeff, L.B. Scientific and regulatory perspectives in herbal and dietary supplement associated hepatotoxicity in the United States. Int. J. Mol. Sci. 2016, 17, 331. [CrossRef] [PubMed] 
12. Danan, G.; Teschke, R. RUCAM in drug and herb induced liver injury: The update. Int. J. Mol. Sci. 2016, 17, 14. [CrossRef] [PubMed]

13. Teschke, R.; Zhang, L.; Melzer, L.; Schulze, J.; Eickhoff, A. Green tea extract and the risk of drug-induced liver injury. Expert Opin. Drug Metab. Toxicol. 2014, 10, 1663-1676. [CrossRef] [PubMed]

14. Zhang, L.; Yan, J.; Liu, X.; Ye, Z.; Yang, X.; Meyboom, R.; Chan, K.; Shaw, D.; Duez, P. Pharmacovigilance practice and risk control of Traditional Chinese Medicine drugs in China: Current status and future perspective. J. Ethnopharmacol. 2012, 140, 519-525.

15. Teschke, R.; Schwarzenboeck, A.; Eickhoff, A.; Frenzel, C.; Wolff, A.; Schulze, J. Clinical and causality assessment in herbal hepatotoxicity. Expert Opin. Drug Saf. 2013, 12, 339-366. [CrossRef] [PubMed]

16. Health Products and Food Branch Marketed Health Products Directorate Canadian Adverse Reaction Newsletter Editorial Team. Available online: http://www.hc-sc.gc.ca/dhp-mps/medeff/ bulletin/carn-bcei_v20n1-eng.php\#a1t1 (accessed on 15 March 2016).

17. Ko, R.J. Adulterants in Asian patent medicines. N. Engl. J. Med. 1998, 339, 847. [CrossRef] [PubMed]

18. Huang, W.F.; Wen, K.C.; Hsiao, M.L. Adulteration by synthetic therapeutic substances of traditional Chinese medicines in Taiwan. J. Clin. Pharmacol. 1997, 37, 344-350. [CrossRef] [PubMed]

19. Espinoza, E.O.; Mann, M.J.; Bleasdell, B. Arsenic and mercury in traditional Chinese herbal balls. N. Engl. J. Med. 1995, 333, 803-804. [CrossRef] [PubMed]

20. Gertner, E.; Marshall, P.S.; Filandrinos, D.; Potek, A.S.; Smith, T.M. Complications resulting from the use of Chinese herbal medications containing undeclared prescription drugs. Arthritis. Rheum. 1995, 38, 614-617. [CrossRef] [PubMed]

21. Kang-Yum, E.; Oransky, S.H. Chinese patent medicine as a potential source of mercury poisoning. Vet. Hum. Toxicol. 1992, 34, 235-238. [PubMed]

22. Navarro, V.J.; Bonkovsky, H.L.; Hwang, S.I.; Vega, M.; Barnhart, H.; Serrano, J. Catechins in dietary supplements and hepatotoxicity. Dig. Dis. Sci. 2013, 58, 2682-2690. [CrossRef] [PubMed]

23. Mazzanti, G.; Menniti-Ippolito, F.; Moro, P.A.; Cassetti, F.; Raschetti, R.; Santuccio, C.; Mastrangelo, S. Hepatotoxicity from green tea: A review of the literature and two unpublished cases. Eur. J. Clin. Pharmacol. 2009, 65, 331-341. [CrossRef] [PubMed]

24. Sarma, D.N.; Barrett, M.L.; Chavez, M.L.; Gardiner, P.; Ko, R.; Mahady, G.B.; Marles, R.J.; Pellicore, L.S.; Giancaspro, G.I.; Low Dog, T. Safety of green tea extract: A systematic review by the US Pharmacopeia. Drug Saf. 2008, 31, 469-484. [CrossRef] [PubMed]

25. Wu, G.L.; Yu, G.Y.; Chen, J. Clinical analysis of hepatic veno-occlusive disease induced by Sedum aizoon. Zhongguo Zhong Yao Za Zhi 2008, 33, 2402-2404. (In Chinese) [PubMed]

26. Lin, G.; Wang, J.Y.; Li, N.; Li, M.; Gao, H.; Ji, Y.; Zhang, F.; Wang, H.; Zhou, Y.; Ye, Y.; et al. Hepatic sinusoidal obstruction syndrome associated with consumption of Gynura segetum. J. Hepatol. 2011, 54, 666-673. [CrossRef] [PubMed]

27. Gao, X.S.; Xiao, S.S.; He, J.F. Analysis of alkaloids in Sedum aizoon and establishment of hepatic veno-occlusive model in mice. Chin. J. Integr. Trad. Western Med. Dig. 2006, 14, 311-313.

28. Gao, H.; Li, N.; Wang, J.Y.; Zhang, S.C.; Lin, G. Definitive diagnosis of hepatic sinusoidal obstruction syndrome induced by pyrrolizidine alkaloids. J. Dig. Dis. 2012, 13, 33-39. [CrossRef] [PubMed]

29. Wang, J.Y.; Gao, H. Tusanqi and hepatic sinusoidal obstruction syndrome. J. Dig. Dis. 2014, 15, $105-107$. [CrossRef] [PubMed]

30. Teschke, R.; Wolff, A.; Frenzel, C.; Schulze, J.; Eickhoff, A. Herbal hepatotoxicity: A tabular compilation of reported cases. Liver Int. 2012, 32, 1543-1556. [CrossRef] [PubMed]

31. Dai, H.F.; Gao, Y.; Yang, M.; Yu, C.H.; Gu, Z.Y.; Chen, W.X. Hepatic veno-occlusive disease induced by Gynura segetum: Report of two cases. Hepatobiliary Pancreat. Dis. Int. 2006, 5, 406-408. [PubMed]

32. Kumana, C.R.; Ng, M.; Lin, H.J.; Ko, W.; Wu, P.C.; Todd, D. Hepatic veno-occlusive disease due to toxic alkaloid in herbal tea. Lancet 1983, 322, 1360-1361. [CrossRef]

33. Kumana, C.R.; Ng, M.; Lin, H.J.; Ko, W.; Wu, P.C.; Todd, D. Herbal tea induced hepatic veno-occlusive disease: Quantification of toxic alkaloid exposure in adults. Gut 1985, 26, 101-104. [CrossRef] [PubMed]

34. Culvenor, C.C.J.; Edgar, J.A.; Smith, L.W.; Kumana, C.R.; Lin, H.J. Heliotropium lasiocarpum Fisch and Mey identified as cause of veno-occlusive disease due to herbal tea. Lancet 1986, 1, 978. [CrossRef]

35. Ernst, E. Heavy metals in traditional Indian remedies. Eur. J. Clin. Pharmacol. 2002, 57, 891-896. [CrossRef] [PubMed] 
36. Ernst, E. Review article. Methodological aspects of Traditional Chinese Medicine (TCM). Ann. Acad. Med. Singap. 2006, 35, 773-774. [PubMed]

37. Saper, R.B.; Phillips, R.S.; Sehgal, A.; Khouri, N.; Davis, R.B.; Paquin, J.; Thuppil, V.; Kalses, S.N. Lead, mercury, and arsenic in US- and Indian-manufactured Ayurvedic medicines sold via the internet. JAMA 2008, 300, 915-923. [CrossRef] [PubMed]

38. Bunchorntavakul, C.; Reddy, K.R. Review article: Herbal and dietary supplement hepatotoxicity. Aliment Pharmacol. Ther. 2013, 37, 3-17. [CrossRef] [PubMed]

39. Dantuluri, S.; North-Lewis, P.; Karthik, S.V. Gotu Kola induced hepatotoxicity in a child-Need for causation with alternative remedies. Dig. Liver Dis. 2011, 43, 500. [CrossRef] [PubMed]

40. Jorge, O.A.; Jorge, A.D. Hepatotoxicity associated with the ingestion of Centella asiatica. Rev. Esp. Enferm. Dig. 2005, 97, 115-124. [CrossRef] [PubMed]

41. Teschke, R.; Bahre, R. Severe hepatotoxicity by Indian Ayurvedic herbal products, A structured causality assessment. Ann. Hepatol. 2009, 8, 258-266. [PubMed]

42. Fleig, W.W.; Morgan, M.Y.; Holzer, M.A. European multicenter study group. The ayurvedic drug Liv.52 in patients with alcoholic cirrhosis. Results of a prospective, randomized, double blind, placebo-controlled clinical trial. J. Hepatol. 1997, 126, 127.

43. Adachi, M.; Saito, H.; Kobayashi, H.; Horie, Y.; Kato, S.; Yoshioka, M.; Ishii, H. Hepatic injury in 12 patients taking the herbal loss aids Chaso and Onshido. Ann. Intern. Med. 2003, 139, 488-492. [CrossRef] [PubMed]

44. Lau, G.; Lo, D.S.; Yao, Y.J.; Leong, H.T.; Chan, C.L.; Chu, S.S. A fatal case of hepatic failure possibly induced by nitrosofenfluramine: A case report. Med. Sci. Law 2004, 44, 252-263. [CrossRef] [PubMed]

45. Kanda, T.; Yokosuka, O.; Okada, O.; Suzuki, Y.; Saisho, H. Severe hepatotoxicity associated with Chinese diet product "Ohnshidou-Genbi-Kounou”. J. Gastroenterol. Hepatol. 2003, 18, 354-355. [CrossRef] [PubMed]

46. Kanda, T.; Yokosuka, O.; Tada, M.; Kurihara, T.; Yoshida, S.; Suzuki, Y.; Nagao, K.; Saisho, H. N-nitroso-fenfluramine hepatotoxicity resembling chronic hepatitis. J. Gastroenterol. Hepatol. 2003, 18, 999-1000. [CrossRef] [PubMed]

47. Teschke, R. Traditional Chinese Medicine induced liver injury. J. Clin. Translat. Hepatol. 2014, 2, 80-94. [CrossRef] [PubMed]

48. Teschke, R.; Schulze, J.; Eickhoff, A.; Wolff, A.; Frenzel, C. Review Article: Mysterious Hawaii liver disease case-Naproxen overdose as cause rather than OxyELITE Pro? J. Liver Clin. Res. 2015, 2, 1013.

49. Teschke, R.; Schwarzenboeck, A.; Frenzel, C.; Schulze, J.; Eickhoff, A.; Wolff, A. The mystery of the Hawaii liver disease cluster in summer 2013: A pragmatic and clinical approach to solve the problem. Ann. Hepatol. 2016, 15, 91-119. [CrossRef] [PubMed]

50. Teschke, R.; Eickhoff, A. The Honolulu Liver disease cluster at the Medical Center: Its mysteries and challenges. Int. J. Mol. Sci. 2016, 17, 476. [CrossRef] [PubMed]

51. Ernst, E. Adulteration of Chinese herbal medicines with synthetic drugs: A systematic review. J. Int. Med. 2002, 252, 107-113. [CrossRef]

52. Efferth, T.; Kaina, B. Toxicities by herbal medicines with emphasis to Traditional Chinese medicine. Curr. Drug Metab. 2011, 12, 989-996. [CrossRef] [PubMed]

53. Shaw, D. Toxicological risks of Chinese herbs. Planta Med. 2010, 76, 2012-2018. [CrossRef] [PubMed]

54. Teschke, R.; Qiu, S.X.; Xuan, T.D.; Lebot, V. Kava and kava hepatotoxicity: Requirements for novel experimental, ethnobotanical, and clinical studies based on a review of the evidence. Phytother. Res. 2011, 25, 1262-1274. [CrossRef] [PubMed]

55. Rowe, A.; Ramzan, I. Letter to the Editor: Are mould hepatotoxins responsible for kava hepatotoxicity? Phytother. Res. 2012, 26, 1768-1770. [CrossRef] [PubMed]

56. Teschke, R.; Sarris, J.; Lebot, V. Contaminant hepatotoxins as culprits for kava hepatotoxicity-Fact or fiction? Phytother. Res. 2013, 27, 472-474. [CrossRef] [PubMed]

57. Teschke, R.; Qiu, S.X.; Lebot, V. Herbal hepatotoxicity by kava: Update on pipermethystine, flavokavain B, and mould hepatotoxins as primarily assumed culprits. Dig. Liver Dis. 2011, 43, 676-681. [CrossRef] [PubMed]

58. Lebot, V. The quality of kava consumed in the South Pacific. HerbalGram 2006, 71, 34-37.

59. Schmidt, M. Quality criteria for kava. HerbalGram 2007, 73, 45-49.

60. Teschke, R.; Lebot, V. Proposal for a Kava Quality Standardization Code. Food Chem. Toxicol. 2011, 49, 2503-2516. [CrossRef] [PubMed] 
61. Sarris, J.; Adams, J.; Wardle, J.L. Editorial: Time for a reassessment of the use of kava in anxiety? Complement. Ther. Med. 2009, 17, 121-122. [CrossRef] [PubMed]

62. Sarris, J.; Teschke, R.; Stough, C.; Scholey, A.; Schweitzer, I. Re-introduction of kava (Piper methysticum) to the EU: Is there a way forward? Planta Med. 2011, 77, 107-110. [CrossRef] [PubMed]

63. Sarris, J.; Kavanagh, D.J. Kava and St. John's wort: Current evidence for use in mood and anxiety disorders. J. Altern. Complement. Med. 2009, 15, 827-836. [CrossRef] [PubMed]

64. Sarris, J.; Kavanagh, D.J.; Byrne, G.; Bone, K.M.; Adams, J.; Deed, G. The Kava Anxiety Depression Spectrum Study (KADSS): A randomized, placebo-controlled crossover trial using an aqueous extract of Piper methysticum. Psychopharmacology 2009, 205, 399-407. [CrossRef] [PubMed]

65. Sarris, J.; Adams, J.; Kavanagh, D. An explorative qualitative analysis of participants' experience of using kava versus placebo in an RCT. Aust. J. Med. Herbalism. 2010, 22, 12-16.

66. Sarris, J.; LaPorte, E.; Schweitzer, I. Kava: A comprehensive review of efficacy, safety, and psychopharmacology. Aust. N. Z. J. Psychiatry 2011, 45, 36-44. [CrossRef] [PubMed]

67. Sarris, J.; Panossian, A.; Schweitzer, I.; Stough, C.; Scholey, A. Herbal medicine for depression, anxiety and insomnia: A review of psychopharmacology and clinical evidence. Eur. Neuropsychopharmacol. 2011, 21, 841-860. [CrossRef] [PubMed]

68. Sarris, J.; Stough, C.; Bousman, C.A.; Wahid, T.; Murray, G.; Teschke, R.; Savage, K.M.; Dowell, A.; $\mathrm{Ng}$, C.; Schweitzer, I. Kava in the treatment of generalized anxiety disorder: A double-blind, randomized, placebo-controlled study. J. Clin. Psychiatry 2013, 33, 643-648. [CrossRef] [PubMed]

69. Savage, K.M.; Stough, C.K.; Byrne, G.J.; Scholey, A.; Bousman, C.; Murphy, J.; Macdonald, P.; Suo, C.; Hughes, M.; Thomas, S.; et al. Kava for the Treatment of Generalised Anxiety Disorder (K-GAD): Study protocol for a randomized controlled trial. Trials 2015, 16, 493. [CrossRef] [PubMed]

70. Ma, X.; Peng, J.H.; Hu, Y.Y. Chinese herbal medicine-induced liver injury. J. Clin. Transl. Hepatol. 2014, 2, 170-175. [CrossRef] [PubMed]

71. Larrey, D.; Faure, S. Herbal medicine hepatotoxicity: A new step with development of specific biomarkers. J. Hepatol. 2011, 54, 599-601. [CrossRef] [PubMed]

72. Larrey, D.; Vial, T.; Pauwels, A.; Castot, A.; Biour, M.; David, M.; Michel, H. Hepatitis after germander (Teucrium chamaedrys) administration: Another instance of herbal medicine hepatotoxicity. Ann. Intern. Med. 1992, 117, 129-132. [CrossRef] [PubMed]

73. Urban, T.J.; Daly, A.K.; Aithal, G.P. Genetic basis of drug-induced liver injury: Present and future. Semin. Liver Dis. 2014, 34, 123-133. [CrossRef] [PubMed]

74. Andrade, R.J.; Robles, M.; Ulzurrun, E.; Lucena, M.I. Drug-induced liver injury: Insights from genetic studies. Pharmacogenomics 2009, 10, 1467-187. [CrossRef] [PubMed]

75. Chen, M.; Borlak, J.; Tong, W. High lipophilicity and high daily dose of oral medications are associated with significant risk for drug-induced liver injury. Hepatology 2013, 58, 388-396. [CrossRef] [PubMed]

76. Lammert, C.; Einarsson, S.; Saha, C.; Niklasson, A.; Bjornsson, E.; Chalasani, N. Relationship between daily dose of oral medications and idiosyncratic drug-induced liver injury: Search for signals. Hepatology 2008, 47, 2003-2009. [CrossRef] [PubMed]

77. Zimmerman, H.J. Hepatotoxicity; Lippincott Williams \& Wilkins: Philadelphia, PA, USA, 1999.

78. Teschke, R.; Frenzel, C.; Glass, X.; Schulze, J.; Eickhoff, A. Greater Celandine hepatotoxicity: A clinical review. Ann. Hepatol. 2012, 11, 838-848. [PubMed]

79. Teschke, R.; Glass, X.; Schulze, J.; Eickhoff, A. Suspected Greater Celandine hepatotoxicity: Liver specific causality evaluation of published case reports from Europe. Eur. J. Gastroenterol. Hepatol. 2012, 24, 270-280. [CrossRef] [PubMed]

80. Teschke, R. Kava hepatotoxicity: A clinical review. Ann. Hepatol. 2010, 9, 251-265. [PubMed]

81. Teschke, R.; Schwarzenboeck, A.; Hennermann, K.H. Kava hepatotoxicity: A clinical survey and critical analysis of 26 suspected cases. Eur. J. Gastroenterol. Hepatol. 2008, 20, 1182-1193. [CrossRef] [PubMed]

82. Teschke, R.; Gaus, W.; Loew, D. Kava extracts: Safety and risks including rare hepatotoxicity. Phytomedicine 2003, 10, 440-446. [CrossRef] [PubMed]

83. Teschke, R.; Schwarzenboeck, A.; Akinci, A. Kava hepatotoxicity: A European view. N. Z. Med. J. 2008, 121, 90-98. [PubMed]

84. Teschke, R.; Wolff, A. Kava hepatotoxicity: Regulatory data selection and causality assessment. Dig. Liver Dis. 2009, 41, 891-901. [CrossRef] [PubMed] 
85. Teschke, R.; Schulze, J. Risk of kava hepatotoxicity and the FDA consumer advisory. J. Am. Med. Assoc. 2010, 304, 2174-2175. [CrossRef] [PubMed]

86. Teschke, R. Kava hepatotoxicity: Pathogenetic aspects and prospective considerations. Liver Int. 2010, 30, 1270-1279. [CrossRef] [PubMed]

87. Teschke, R. Special report. Kava and the risk of liver toxicity: Past, current, and future. Am. Herb. Prod. Assoc. 2011, 26, 1-17.

88. Teschke, R.; Wolff, A. Regulatory causality evaluation methods applied in kava hepatotoxicity: Are they appropriate? Regul. Toxicol. Pharmacol. 2011, 59, 1-7. [CrossRef] [PubMed]

89. Olsen, L.R.; Grillo, M.P.; Skonberg, C. Constituents in kava extracts potentially involved in hepatotoxicity: A review. Chem. Res. Toxicol. 2011, 24, 992-1002. [CrossRef] [PubMed]

90. Martin, A.C.; Johnston, E.; Xing, C.; Hegeman, A.D. Measuring the chemical and cytotoxic variability of commercially available kava (Piper methysticum G. Forster). PLoS ONE 2014, 9, e111572. [CrossRef] [PubMed]

91. Schmidt, M. German court ruling reverses kava ban; German regulatory authority appeals decision. HerbalGram 2014, 103, 38-42.

92. Kuchta, K.; Schmidt, M.; Nahrstedt, A. German kava ban lifted by court: The alleged hepatotoxicity of kava (Piper methysticum) as a case of ill-defined herbal drug identity, lacking quality control, and misguided regulatory politics. Planta Med. 2015, 81, 1647-1653. [CrossRef] [PubMed]

93. Verwaltungsgericht Köln, 7 K 2197/12. Available online: http://www.justiz.nrw.de/nrwe/ovgs/vg_koeln/ j2014/7_K_2197_12_Urteil_20140520.html (accessed on 15 March 2016).

94. BfArM. Bundesinstitut für Arzneimittel und Medizinprodukte, Bonn. Federal Institute for Drugs and Medicinal Products in Germany. Rejection of Drug Risks, Step II. As related to: Kava-Kava (Piper methysticum)-containing, and kavain-containing drugs, including homeopathic preparations with a final concentration up to, and including D4. 14 June 2002. Available online: http://www.spc.int/ cis/documents/02_0714_BfArM_Kava_Removal.pdf (accessed on 15 March 2016).

95. Fu, P.P.; Xia, Q.; Lin, G.; Chou, M.W. Pyrrolizidine alkaloids-Genotoxicity, metabolism enzymes, metabolic activation, and mechanisms. Drug Metab. Rev. 2004, 36, 1-55. [CrossRef] [PubMed]

96. Roulet, M.; Laurini, R.; Rivier, L.; Calame, A. Hepatic veno-occlusive disease in newborn infant of a woman drinking herbal tea. J. Pediatr. 1988, 112, 433-436. [CrossRef]

97. Lee, C.H.; Wang, J.D.; Chen, P.C. Risk of liver injury associated with Chinese herbal products containing Radix bupleuri in 639,779 patients with hepatitis B virus infection. PLoS ONE 2011, 6, e16064. [CrossRef] [PubMed]

98. Liu, Y.; Li, Z.; Liu, X.; Pan, R. Review on the toxic effects of radix Bupleuri. Curr. Opin. Complement. Altern. Med. 2014, 1, 3-7.

99. Lei, X.; Chen, J.; Ren, J.; Li, Y.; Zhai, J.; Mu, W.; Zhang, L.; Zheng, W.; Tian, G.; Shang, H. Liver damage associated with Polygonum multiflorum Thunb.: A systematic review of case reports and case series. Evid. Based Complement. Altern. Med. 2015, 4597949. [CrossRef]

100. Mazzanti, G.; di Soto, A.; Vitalone, A. Hepatotoxicity of green tea: An update. Arch. Toxicol. 2015, 89, 1175-1191. [CrossRef] [PubMed]

101. Chau, T.N.; Cheung, W.I.; Ngan, T.; Lin, J.; Lee, K.W.S.; Poon, W.T.; Leung, V.K.S.; Mak, T.; Tse, M.L.; the Hong Kong Herb-Induced Liver Injury Network (HK-HILIN). Causality assessment of herb-induced liver injury using multidisciplinary approach and the Roussel Uclaf Causality assessment Method (RUCAM). Clin. Toxicol. 2011, 49, 34-39. [CrossRef] [PubMed]

102. Zhou, Y.; Qin, S.; Wang, K. Biomarkers of drug-induced liver injury. Curr. Biomark. Find 2013, 3, 1-9.

103. Yang, X.; Salminen, W.F.; Schnackenberg, L.K. Current and emerging biomarkers of hepatotoxicity. Curr. Biomark. Find 2012, 2, 43-55.

104. Chalasani, N.; Björnsson, E. Risk factors for idiosyncratic drug-induced liver injury. Gastroenterology 2010, 138, 2246-2259. [CrossRef] [PubMed]

105. Mahady, G.B.; Low Dog, T.; Barrett, M.L.; Chavez, M.L.; Gardiner, P.; Ko, R.; Marles, R.J.; Pellicore, L.S.; Giancaspro, G.I.; Sarma, D.N. United States Pharmacopeia review of the black cohosh case reports of hepatotoxicity. Menopause 2008, 15, 628-638. [CrossRef] [PubMed]

106. Teschke, R.; Bahre, R.; Genthner, A.; Fuchs, J.; Schmidt-Taenzer, W.; Wolff, A. Suspected black cohosh hepatotoxicity-Challenges and pitfalls of causality assessment. Maturitas 2009, 63, 302-314. [CrossRef] [PubMed] 
107. Teschke, R. Black cohosh and suspected hepatotoxicity-Inconsistencies, confounding variables, and prospective use of a diagnostic causality algorithm: A critical review. Menopause 2010, 17, 426-440. [CrossRef] [PubMed]

108. Teschke, R.; Schulze, J. Suspected herbal hepatotoxicity: Requirements for appropriate causality assessment by the US Pharmacopeia. Drug Saf. 2012, 12, 1091-1097. [CrossRef]

109. Teschke, R.; Schmidt-Taenzer, W.; Wolff, A. Spontaneous reports of assumed herbal hepatotoxicity by black cohosh: Is the liver unspecific Naranjo scale precise enough to ascertain causality? Pharmacoepidemiol. Drug Saf. 2011, 20, 567-582. [CrossRef] [PubMed]

110. Teschke, R.; Schwarzenboeck, A.; Schmidt-Taenzer, W.; Wolff, A.; Hennermann, K.H. Herb induced liver injury presumably caused by black cohosh: A survey of initially purported cases and herbal quality specifications. Ann. Hepatol. 2011, 11, 249-259.

111. Liss, G.; Lewis, J.H. Drug-induced liver injury: What was new in 2008? Expert Opin. Drug Metab. Toxicol. 2009, 5, 843-860. [CrossRef] [PubMed]

112. World Health Organization. Assessments of the Risk of Hepatotoxicity with Kava Products; WHO Document Production Services: Geneva, Switzerland, 2007.

113. BfArM, Bundesinstitut für Arzneimittel und Medizinprodukte (German regulatory agency). Bekanntmachung. Abwehr von Gefahren durch Arzneimittel, Stufe II, Anhörung: Schöllkraut-haltige Arzneimittel zur innerlichen Anwendung. 6 May 2005. Available online: http://www.bfarm.de/ cae/servlet/contentblob/1014620/publicationFile/66198/schoellkraut-anhoerung_050505.pdf (accessed on 15 March 2016).

114. Schmidt, M.; Morgan, M.; Bone, K.; McMillan, J. Kava: A risk-benefit assessment. In The Essential Guide to Herbal Safety; Mills, M., Bone, K., Eds.; Elsevier Churchill Livingstone: St. Louis, MS, USA, 2005; pp. 155-221.

115. DCGMA, Drug Commission of the German Medical Association (Arzneimittelkommission der Deutschen Ärzteschaft). Hepatitis in connection with Umckaloabo ${ }^{\circledR}$. Deutsches Ärzteblatt 2011, 108, C1399-C1400. (In German)

116. Teschke, R.; Frenzel, C.; Schulze, J.; Eickhoff, A. Spontaneous reports of primarily suspected herbal hepatotoxicity by Pelargonium sidoides: Was causality adequately ascertained? Regul. Toxicol. Pharmacol. 2012, 63, 1-9. [CrossRef] [PubMed]

117. Teschke, R.; Frenzel, C.; Schulze, J.; Eickhoff, A. Suspected herbal hepatotoxicity: The pharmacovigilance dilemma with disputed and obsolete evaluation methods. Regul. Toxicol. Pharmacol. 2012, 64, 343-344. [CrossRef]

118. Teschke, R.; Frenzel, C.; Wolff, A.; Herzog, J.; Glass, X.; Schulze, J.; Eickhoff, A. Initially purported hepatotoxicity by Pelargonium sidoides: The dilemma of pharmacovigilance and proposals for improvements. Ann. Hepatol. 2012, 11, 500-512. [PubMed]

119. Teschke, R.; Frenzel, C.; Schulze, J.; Schwarzenboeck, A.; Eickhoff, A. Herbalife hepatotoxicity: Evaluation of cases with positive reexposure tests. World J. Hepatol. 2013, 5, 353-363. [CrossRef] [PubMed]

120. Melchart, D.; Linde, K.; Weidenhammer, W.; Hager, S.; Shaw, D.; Bauer, R. Liver enzyme elevations in patients treated with traditional Chinese medicine. JAMA 1999, 282, 28-29. [CrossRef] [PubMed]

121. Au, J.S.; Navarro, V.J.; Rossi, S. Review article: Drug induced liver injury-Its pathophysiology and evolving diagnostic tools. Aliment. Pharmacol. Ther. 2011, 34, 11-20. [CrossRef] [PubMed]

122. Dalton, H.R.; Fellows, H.J.; Stableforth, W.; Joseph, M.; Thurairajah, P.H.; Warshow, U.; Hazeldine, S.; Remnarace, R.; Ijaz, S.; Hussaini, S.H.; et al. The role of hepatitis E virus testing in drug-induced liver injury. Aliment. Pharmacol. Ther. 2007, 26, 1429-1435. [CrossRef] [PubMed]

123. Davern, T.J.; Chalasani, N.; Fontana, R.J.; Hayashi, P.H.; Protiva, P.; Kleiner, D.E.; Engle, R.E.; Nguyen, H.; Emerson, S.U.; Purcell, R.H.; et al. Acute hepatitis E infection accounts for some cases of suspected drug-induced liver injury. Gastroenterology 2011, 141, 1665-1672. [CrossRef] [PubMed]

124. Hoofnagle, J.H.; Nelson, K.E.; Purcell, R.H. Review article: Hepatitis E. N. Engl. J. Med. 2012, 367, 1237-1244. [CrossRef] [PubMed]

125. Teschke, R.; Andrade, R. Editorial. Drug-induced liver injury: Expanding our knowledge by enlarging population analysis with prospective and scoring causality assessment. Gastroenterology 2015, 148, 1271-1273. [CrossRef] [PubMed]

126. Chen, E.Y.; Baum, K.; Collins, W.; Löve, A.; Merz, M.; Olafsson, S.; Björnsson, E.S.; Lee, W.M. Hepatitis E masquerading as drug-induced liver injury. Hepatology 2012, 56, 2420-2423. [CrossRef] [PubMed] 
127. Bénichou, C.; Danan, G.; Flahault, A. Causality assessment of adverse reactions to drugs-II. An original model for validation of drug causality assessment methods: Case reports with positive rechallenge. J. Clin. Epidemiol. 1993, 46, 1331-1336. [CrossRef]

128. Teschke, R.; Zhang, L.; Long, H.; Schwarzenboeck, A.; Schmidt-Taenzer, W.; Genthner, A.; Wolff, A.; Frenzel, C.; Schulze, J.; Eickhoff, A. Traditional Chinese Medicine and herbal hepatotoxicity: A tabular compilation of reported cases. Ann. Hepatol. 2015, 14, 7-19. [PubMed]

129. Teschke, R.; Genthner, A.; Wolff, A.; Frenzel, C.; Schulze, J.; Eickhoff, A. Herbal hepatotoxicity: Analysis of cases with initially reported positive reexposure tests. Dig. Liver Dis. 2014, 46, 264-269. [CrossRef] [PubMed]

130. National Institutes of Health (NIH) and LiverTox: Drug record. Ba Jiao Lian (Dysosma pleianthum). Last updated 19 May 2014. Available online: http://livertox.nih.gov/BaJiaoLian.htm (accessed on 15 March 2016).

131. Naser, B.; Schnitker, J.; Minkin, M.J.; de Arriba, S.G.; Nolte, K.U.; Osmers, R. Hepatotoxicity suspected by black cohosh: No evidence by metaanalysis of randomized controlled clinical trials for isopropanolic black cohosh extract. Menopause 2011, 18, 366-375. [CrossRef] [PubMed]

132. Teschke, R.; Schulze, J.; Schwarzenboeck, A.; Eickhoff, A.; Frenzel, C. Herbal hepatotoxicity: Suspected cases assessed for alternative causes. Eur. J. Gastroenterol. Hepatol. 2013, 25, 1093-1098. [CrossRef] [PubMed]

133. Teschke, R.; Frenzel, C.; Wolff, A.; Eickhoff, A.; Schulze, J. Drug induced liver injury: Accuracy of diagnosis in published reports. Ann. Hepatol. 2014, 13, 248-255. [PubMed]

134. Navarro, V.J.; Barnhart, H.; Bonkovsky, H.L.; Davern, T.; Fontana, R.J.; Grant, L.; Reddy, K.R.; Seeff, L.B.; Serrano, J.; Averell, H.; et al. Liver injury from herbals and dietary supplements in the U.S. Drug-Induced Liver Injury Network. Hepatology 2014, 60, 1399-1408. [CrossRef] [PubMed]

135. Teschke, R.; Glass, X.; Schulze, J. Herbal hepatotoxicity by Greater Celandine (Chelidonium majus): Causality assessment of 22 spontaneous reports. Regul. Toxicol. Pharmacol. 2011, 61, 282-291. [CrossRef] [PubMed]

136. Haller, C.A.; Dyer, J.E.; Ko, R.; Olson, K.R. Making a diagnosis of herbal-related toxic hepatitis. West J. Med. 2002, 176, 39-44. [CrossRef] [PubMed]

137. Estes, J.D.; Stolpman, D.; Olyaei, A.; Corless, C.L.; Ham, J.M.; Schwartz, J.M.; Orloff, S. High prevalence of potentially hepatotoxic herbal supplement use in patients with fulminant hepatic failure. Arch. Surg. 2003, 138, 852-858. [CrossRef] [PubMed]

138. Talari, P.; Talari, G.; Gundareddy, V.; Vemula, P.; Barmecha, J. Acute Hepatitis Associated with the Chinese Herbal Product bai shi wan. Available online: http://www.toothpicks.info/rc2/ posters/2010/Internal_Medicine/Talari_P_Acute_hepatitis_associated.pdf (accessed on 15 March 2016).

139. Perharic-Walton, L.; Murray, V. Toxicity of Chinese herbal remedies. Lancet 1992, 340, 674. [PubMed]

140. Kane, J.A.; Kane, S.P.; Jain, S. Hepatitis induced by traditional Chinese herbs: Possible toxic components. Gut 1995, 36, 146-147. [CrossRef] [PubMed]

141. Vautier, G.; Spiller, R.C. Safety of complementary medicines should be monitored. BMJ 1995, $311,633$. [CrossRef] [PubMed]

142. Yuen, M.F.; Tam, S.; Fung, J.; Wong, D.K.H.; Wong, B.C.Y.; Lai, C.L. Traditional Chinese Medicine causing hepatotoxicity in patients with chronic hepatitis B infection: A 1-year prospective study. Aliment. Pharmacol. Ther. 2006, 24, 1179-1186. [CrossRef] [PubMed]

143. Kang, S.H.; Kim, J.I.; Jeong, K.H.; Ko, K.H.; Ko, P.G.; Hwang, S.W.; Kim, E.M.; Kim, S.H.; Lee, H.Y.; Lee, B.S. Clinical characteristics of 159 cases of acute toxic hepatitis. Korean J. Hepatol. 2008, 14, 483-492, (abstract in English, article in Korean). [CrossRef] [PubMed]

144. Sohn, C.H.; Cha, M.I.; Oh, B.J.; Yeo, W.H.; Lee, J.H.; Kim, W.; Lim, K.S. Liver transplantation for acute toxic hepatitis due to herbal medicines and preparations. J. Korean Soc. Clin. Toxicol. 2008, 6, 110-116, (abstract in English, article in Korean).

145. Cortez, E.; Boulger, C.; Bernard, A. Ban Tu Wan hepatotoxicity. BMJ Case Rep. 2012. [CrossRef] [PubMed]

146. Sangsuwan, C.; Udompanthurak, S.; Vannasaeng, S.; Thamlikitkul, V. Randomized controlled trial of Tinospora crispa for additional therapy in patients with type 2 diabetes mellitus. J. Med. Assoc. Thai. 2004, 87, 543-546, (abstract in English, article in Thai). [PubMed]

147. Motoyama, H.; Enomoto, M.; Yasuda, T.; Fujii, H.; Kobayashi, S.; Iwai, S.; Morikawa, H.; Takeda, T.; Tamori, A.; Sakaguchi, H.; et al. Drug-induced liver injury caused by a herbal medicine, bofu-tsu-sho-san. Nihon Shokakibyo Gakkai Zasshi 2008, 105, 1234-1239, (abstract in English, article in Japanese). [PubMed] 
148. Hwang, S.H.; Park, J.A.; Jang, Y.S.; Lee, K.M.; Lee, D.S.; Ahn, B.M.; Lee, E.H. Case of acute cholestatic hepatitis caused by the seeds of Psoralea-corylifolia. Korean J. Hepatol. 2001, 7, 341-344, (abstract in English, article in Korean).

149. Nam, S.W.; Baek, J.T.; Lee, D.S.; Kang, S.B.; Ahn, B.M.; Chung, K.W. A case of acute cholestatic hepatitis associated with the seeds of Psoralea corylifolia (Boh-Gol-Zhee). Clin. Toxicol. 2005, 43, 589-591. [CrossRef]

150. Cheung, W.I.; Tse, M.L.; Ngan, T.; Lin, J.; Lee, W.K.; Poon, W.T.; Mak, T.W.; Leung, V.K.S.; Chau, T.N. Liver injury associated with the use of Fructus Psoraleae (Bol-gol-zhee or Bu-gu-zhi) and its related propriety medicine. Clin. Toxicol. 2009, 47, 683-685. [CrossRef] [PubMed]

151. Chau, T.N. Drug-induced liver injury: An update. Hong Kong Med. Diary 2008, 13, $23-26$.

152. Lin, T.J.; Tsai, M.S.; Chiou, N.M.; Deng, J.F.; Chiu, N.Y. Hepatotoxicity caused by Breynia officinalis. Vet. Hum. Toxicol. 2002, 44, 87-88. [PubMed]

153. Lin, T.J.; Su, C.C.; Lan, C.K.; Jiang, D.D.; Tsai, J.L.; Tsai, M.S. Acute poisonings with Breynia officinalis-An outbreak of hepatotoxicity. J. Toxicol. Clin. Toxicol. 2003, 41, 591-594. [CrossRef] [PubMed]

154. Yoshida, E.M.; McLean, C.A.; Cheng, E.S.; Blanc, P.D.; Somberg, K.A.; Ferrell, L.D.; Lake, J.R. Chinese herbal medicine, fulminant hepatitis, and liver transplantation. Am. J. Gastroenterol. 1996, 91, 2647-2648. [PubMed]

155. Kamiyama, T.; Nouchi, T.; Kojima, S.; Murata, N.; Ikeda, T.; Sato, C. Autoimmune hepatitis triggered by administration of an herbal medicine. Am. J. Gastroenterol. 1997, 92, 703-704. [PubMed]

156. Björnsson, E.S.; Bergmann, O.M.; Björnsson, H.K.; Kvaran, R.B.; Olafsson, S. Incidence, presentation and outcomes in patients with drug-induced liver injury in the general population of Iceland. Gastroenterology 2013, 144, 1419-1425. [CrossRef] [PubMed]

157. Verucchi, G.; Calza, L.; Attard, L.; Chiodo, F. Acute hepatitis induced by traditional Chinese herbs used in the treatment of psoriasis. J. Gastroenterol. Hepatol. 2002, 17, 1342-1343. [CrossRef] [PubMed]

158. Kim, S.Y.; Yim, H.J.; Ahn, J.H.; Kim, J.H.; Kim, J.N.; Yoon, I.; Kim, D.I.; Lee, H.S.; Lee, S.W.; Choi, J.H. Two cases of toxic hepatitis caused by arrowroot juice. Korean J. Hepatol. 2009, 15, 504-509, (abstract in English, article in Korean). [CrossRef] [PubMed]

159. Bae, S.H.; Kim, D.H.; Bae, Y.S.; Lee, K.J.; Kim, D.W.; Yoon, J.B.; Hong, J.H.; Kim, S.H. Toxic hepatitis associated with Polygoni multiflori. Korean J. Hepatol. 2010, 16, 182-186, (abstract in English, article in Korean). [CrossRef] [PubMed]

160. Gono, Y.; Odaguchi, H.; Hayasaki, T.; Suzuki, K.; Oikawa, T.; Muranushi, A.; Akahoshi, T.; Hanawa, T. Clinical analysis of cases with drug-induced liver injury for Kampo medicine. Kampo Med. 2010, 61, 828-833, (abstract in English, article in Japanese). [CrossRef]

161. Linnebur, S.A.; Rapacchietta, O.C.; Vejar, M. Hepatotoxicity associated with Chinese skullcap contained in Move Free Advanced dietary supplement: Two case reports and review of the literature. Pharmacotherapy 2010, 750, 258e-262e. [CrossRef]

162. Yang, L.; Aronsohn, A.; Hart, J.; Jensen, D. Herbal hepatotoxicity from Chinese skullcap: A case report. World J. Hepatol. 2012, 4, 231-233. [CrossRef] [PubMed]

163. Dhanasekaran, R.; Owens, V.; Sanchez, W. Chinese skullcap in Move Free arthritis supplement causes drug induced liver injury and pulmonary infiltrates. Case Rep. Hepatol. 2013, 965092. [CrossRef] [PubMed]

164. Kang, H.S.; Choi, H.S.; Yun, T.J.; Lee, K.G.; Seo, Y.S.; Yeon, J.E.; Byun, K.S.; Um, S.H.; Kim, C.D.; Ryu, H.S. A case of acute cholestatic hepatitis induced by Corydalis speciosa Max. Korean J. Hepatol. 2009, 15, 517-523. (In Korean) [CrossRef] [PubMed]

165. Kim, Y.J.; Ryu, S.L.; Shim, J.W.; Kim, D.S.; Shim, J.Y.; Park, M.S.; Jung, H.L. A pediatric case of toxic hepatitis induced by Hovenia dulcis. Pediatr. Gastroenterol. Hepatol. Nutr. 2012, 15, 111-116. [CrossRef]

166. Woolf, G.M.; Petrovic, L.M.; Rojter, S.E.; Wainwright, S.; Villamil, F.G.; Katkov, W.N.; Michieletti, P.; Wanless, I.R.; Stermitz, F.R.; Beck, J.J.; et al. Acute hepatitis associated with the Chinese herbal product Jin Bu Huan. Ann. Intern. Med. 1994, 121, 729-735. [CrossRef] [PubMed]

167. Horowitz, R.S.; Feldhaus, K.; Dart, R.C.; Stermitz, F.R.; Beck, J.J. The clinical spectrum of Jin Bu Huan toxicity. Arch Intern. Med. 1996, 156, 899-903. [CrossRef] [PubMed]

168. Picciotti, A.; Campo, N.; Brizzolara, R.; Giusto, R.; Guido, G.; Sinelli, N.; Lapertosa, G.; Celle, G. Chronic hepatitis induced by Jin Bu Huan. J. Hepatol. 1998, 28, 165-167. [CrossRef]

169. Divinsky, M. Case report: Jin Bu Huan-Not so benign herbal medicine. Can Fam. Phys. 2002, 48, 1640-1642.

170. Inoue, H.; Yamazaki, S.; Shimizu, M.; Uozki, H.; Goto, T.; Ohnishi, S.; Koike, K. Liver injury induced by the Japanese herbal drug kamishoyosan. Gastroenterol. Hepatol. 2011, 7, 692-695. 
171. Garcia-Moran, S.; Saez-Royuela, F.; Gento, E.; Lopez Morante, A.; Arias, L. Acute hepatitis associated with Camellia tea and Orthosiphon stamineus ingestion. Gastroenterol. Hepatol. 2004, 27, 559-560. [CrossRef]

172. Peyrin-Biroulet, L.; Petitpain, N.; Kalt, P.; Ancel, D.; Petit-Laurent, F.; Trechot, P.; Barraud, H.; Bronowicki, J.P. Probable hepatotoxicity from epigallocatecol gallate used for Phytotherapy. Gastroenterol. Clin. Biol. 2004, 28, 404-406. (In French) [CrossRef]

173. Gloro, R.; Hourmand-Ollivier, I.; Mosquet, B.; Mosquet, L.; Rousselot, P.; Salamé, E.; Piquet, M.A.; Dao, T. Fulminant hepatitis during self-medication with hydroalcoholic extract of green tea. Eur. J. Gastroenterol. Hepatol. 2005, 17, 1135-1137. [CrossRef] [PubMed]

174. Javaid, A.; Bonkovsky, H.L. Hepatotoxicity due to extracts of Chinese green tea (Camellia sinensis): A growing concern. J. Hepatol. 2006, 45, 334-335. [CrossRef] [PubMed]

175. Jimenez-Saenz, M.; Martinez-Sanchez M del, C. Acute hepatitis associated with the use of green tea infusions. J. Hepatol. 2006, 44, 616-617. [CrossRef] [PubMed]

176. Bonkovsky, H.L. Hepatotoxicity associated with supplements containing Chinese green tea (Camellia sinensis). Ann. Intern. Med. 2006, 144, 68-71. [CrossRef] [PubMed]

177. Molinari, M.; Watt, K.D.; Kruszyna, T.; Nelson, R.; Walsh, M.; Huang, W.Y.; Nashan, B.; Peltekian, K. Acute liver failure induced by green tea extracts: Case reports and review of the literature. Liver Transpl. 2006, 12, 1892-1895. [CrossRef] [PubMed]

178. Björnsson, E.; Olsson, R. Serious adverse liver reactions associated with herbal weight loss supplements. J. Hepatol. 2007, 47, 295-297. [CrossRef] [PubMed]

179. García-Cortés, M.; Borraz, Y.; Lucena, M.I.; Peláez, G.; Salmerón, J.; Diago, M.; Martínez-Sierra, M.C.; Navarro, J.M.; Planas, R.; Soria, M.J.; et al. Liver injury induced by "natural remedies": An analysis of cases submitted to the Spanish Liver Toxicity Registry. Rev. Esp. Enferm. Dig. 2008, 100, 688-695. [PubMed]

180. Rohde, J.; Jacobsen, C.; Kromann-Andersen, H. Toxic hepatitis triggered by green tea. Ugeskr Laeger 2011, 173, 205-206, (abstract in English, article in Danish). [PubMed]

181. Nadir, A.; Agrawal, S.; King, P.D.; Marshall, J.B. Acute hepatitis associated with the use of a Chinese herbal product, ma-huang. Am. J. Gastroenterol. 1996, 91, 1436-1438. [PubMed]

182. Borum, M.L. Fulminant exacerbation of autoimmune hepatitis after the use of Ma Huang. Am. J. Gastroenterol. 2001, 96, 1654-1655. [CrossRef] [PubMed]

183. Skoulidis, F.; Alexander, G.J.; Davies, S.E. Ma huang associated acute liver failure requiring liver transplantation. Eur. J. Gastroenterol. Hepatol. 2005, 17, 581-584. [CrossRef] [PubMed]

184. Reuben, A.; Koch, D.G.; Lee, W.M.; the Acute Liver Failure Study Group. Drug-induced acute liver failure: Results of a U.S. multicenter, prospective study. Hepatology 2010, 52, 2065-2076. [CrossRef] [PubMed]

185. Aiba, T.; Takahashi, T.; Suzuki, K.; Okoshi, S.; Nomoto, M.; Uno, K.; Aoyagi, Y. Liver injury induced by a Japanese herbal medicine, sairei-to (TJ-114, Bupleurum and Hoelen combination, Chai-Ling-Tang). J. Gastroenterol. Hepatol. 2007, 22, 762-763. [CrossRef] [PubMed]

186. Tsuda, T.; Yashiro, S.; Gamo, Y.; Watanabe, K.; Hoshino, T.; Oikawa, T.; Hanawa, T. Discrepancy between clinical course and drug-induced lymphocyte stimulation tests in a case of saireito-induced liver injury accompanied by Sjögren syndrome. J. Altern. Complement. Med. 2010, 16, 501-505. [CrossRef] [PubMed]

187. Chen, M.Y.; Cai, J.T.; Du, Q. Hepatic veno-occlusive disease associated with the use of Gynura segetum. Eur. J. Intern. Med. 2007, 18, 609. [CrossRef] [PubMed]

188. Li, C.; Liang, X.S.; Li, C.Z. Sinusoidal obstruction syndrome associated with the ingestion of Gynura root. Clin. Toxicol. 2010, 48, 962-964. [CrossRef] [PubMed]

189. Cárdenas, A.; Restrepo, J.C.; Sierra, F.; Correa, G. Acute hepatitis due to shen-min: A herbal product derived from Polygonum multiflorum. J. Clin. Gastroenterol. 2006, 40, 629-632. [CrossRef] [PubMed]

190. But, P.P.H.; Tomlinson, B.; Lee, K.L. Hepatitis related to the Chinese medicine Shou-wu-pian manufactured from Polygonum multiflorum. Vet. Hum. Toxicol. 1996, 38, 280-282. [PubMed]

191. Park, G.J.H.; Mann, S.P.; Ngu, M.C. Acute hepatitis induced by Shou-Wu-Pian, a herbal product derived from Polygonum multiflorum. J. Gastroenterol. Hepatol. 2001, 16, 115-117. [CrossRef] [PubMed]

192. Battinelli, L.; Daniele, C.; Mazzanti, G.; Mastroianni, C.M.; Lichtner, M.; Coletta, S.; Costantini, S. New case of acute hepatitis following the consumption of Shou Wu Pian, a Chinese herbal product derived from Polygonum multiflorum. Ann. Intern. Med. 2004, 140, 587-588. 
193. Panis, B.; Wong, D.R.; Hooymans, P.M.; De Smet, P.A.G.M.; Rosias, P.R. Recurrent toxic hepatitis in a Caucasian girl related to the use of Shou-Wu-Pian, a Chinese herbal preparation. J. Pediat. Gastroenterol. Nutr. 2005, 41, 256-258. [CrossRef]

194. Laird, A.R.; Ramchandani, N.; deGoma, E.M.; Avula, B.; Khan, I.A.; Gesundheit, N. Acute hepatitis associated with the use of an herbal supplement (Polygonum multiflorum) mimicking iron-overload syndrome. Clin. Gastroenterol. 2008, 42, 861-862. [CrossRef] [PubMed]

195. Furukawa, M.; Kasajima, S.; Nakamura, Y.; Shouzushima, M.; Nagatani, N.; Takinishi, A.; Taguchi, A.; Fujita, M.; Niimi, A.; Misaka, R.; et al. Toxic hepatitis induced by Show-Wu-Pian, a Chinese herbal preparation. Intern. Med. 2010, 49, 1537-1540. [CrossRef] [PubMed]

196. Valente, G.; Sanges, M.; Campione, S.; Bellevicine, C.; de Franchis, G.; Sollazzo, R.; Matera, D.; Cimino, L.; Vecchione, R.; D’Arienzo, A. Herbal hepatotoxicity: A case of difficult interpretation. Eur. Rev. Med. Pharmacol. Sci. 2010, 14, 865-870. [CrossRef]

197. Jung, K.A.; Min, H.J.; Yoo, S.S.; Kim, H.J.; Choi, S.N.; Ha, C.Y.; Kim, H.J.; Kim, T.H.; Jung, W.T.; Lee, O.J.; et al. Drug-induced liver injury: Twenty five cases of acute hepatitis following ingestion of Polygonum multiflorum Thun. Gut Liver 2011, 5, 493-499. [CrossRef] [PubMed]

198. Banarova, A.; Koller, T.; Payer, J. Toxic hepatitis induced by Polygonum multiflorum. Vnitr Lek 2012, 58, 958-962, (abstract in English, article in Slovak). [PubMed]

199. Cohen, S.M.; Heywood, E.; Pillai, A.; Ahn, J. Hepatotoxicity associated with the use of White Flood, a nutritional supplement. Pract. Gastroenterol. 2012, 10, 45-48.

200. Itoh, S.; Marutani, K.; Nishijima, T.; Matsuo, S.; Itabashi, M. Liver injuries induced by herbal medicine, Syo-saiko-to (xiao-chai-hu-tang). Dig. Dis. Sci. 1995, 40, 1845-1848. [CrossRef] [PubMed]

201. Hsu, L.M.; Huang, Y.S.; Tsay, S.H.; Chang, F.Y.; Lee, S.D. Acute hepatitis induced by Chinese hepatoprotective herb xiao-chai-hu-tang. J. Chin. Med. Assoc. 2006, 69, 86-88. [CrossRef]

202. Rabe, C.; Musch, A.; Schirrmacher, P.; Kruis, W.; Hoffmann, R. Acute hepatitis induced by an aloe vera preparation: A case report. World J. Gastroenterol. 2005, 11, 303-304. [CrossRef] [PubMed]

203. Kanat, O.; Ozet, A.; Ataegin, S. Aloe vera-induced acute toxic hepatitis in a healthy young man. Eur. J. Intern. Med. 2006, 17, 589. [CrossRef] [PubMed]

204. Bottenberg, M.M.; Wall, G.C.; Harvey, R.L.; Habib, S. Oral Aloe vera-induced hepatitis. Ann. Pharmacother. 2007, 41, 1740-1743. [CrossRef] [PubMed]

205. Yang, H.N.; Kim, D.J.; Kim, Y.M.; Kim, B.H.; Sohn, K.M.; Choi, M.J.; Choi, Y.H. Aloe-induced toxic hepatitis. J. Korean Med. Sci. 2010, 25, 492-495. [CrossRef] [PubMed]

206. Smith, L.W.; Culvenor, C.C.J. Plant sources of hepatotoxic pyrrolizidine alkaloids. J. Nat. Prod. 1981, 44, 129-152. [CrossRef] [PubMed]

207. Nadir, A.; Reddy, D.; van Thiel, D.H. Cascara sagrada-induced intrahepatic cholestasis causing portal hypertension: Case report and review of herbal hepatotoxicity. Am. J. Gastroenterol. 2000, 95, 3634-3637. [CrossRef] [PubMed]

208. Katz, M.; Saibil, F. Herbal hepatitis: Subacute hepatic necrosis secondary to chaparral leaf. J. Clin. Gastroenterol. 1990, 12, 203-206. [CrossRef] [PubMed]

209. Centers of Disease Control and Prevention. Chaparral-induced toxic hepatitis California and Texas 1992. J. Am. Med. Ass. 1992, 268, 3295-3298.

210. Smith, B.C.; Desmond, P.V. Acute hepatitis induced by the ingestion of the herbal medication chaparral. Aust. N. Z. J. Med. 1993, 23, 526. [CrossRef] [PubMed]

211. Alderman, S.; Goldfarb, S.; Malone, D.G. Cholestatic hepatitis after ingestion of chaparral leaf: Confirmation by endoscopic retrograde cholangio-pancreatography and liver biopsy. J. Clin. Gastroenterol. 1994, 19, 242-247. [CrossRef] [PubMed]

212. Batchelor, W.B.; Heathcote, J.; Wanless, I.R. Chaparral-induced hepatic injury. Am. J. Gastroenterol. 1995, 90, 831-833. [PubMed]

213. Gordon, D.W.; Rosenthal, G.; Hart, J.; Sirota, S.; Baker, A.L. Chaparral ingestion: The broadening spectrum of liver injury caused by herbal medications. J. Am. Med. Assoc. 1995, 273, 489-490. [CrossRef]

214. Sheikh, N.M.; Philen, R.M.; Love, L.A. Chaparral-associated hepatotoxicity. Arch. Intern. Med. 1997, 157, 913-919. [CrossRef] [PubMed] 
215. Ridker, P.M.; Ohkuma, S.; McDermott, W.V.; Trey, C.; Huxtable, R.J. Hepatic venoocclusive disease associated with the consumption of pyrrolizidine-containing dietary supplements. Gastroenterology 1985, 88, 1050-1054. [PubMed]

216. Weston, C.F.M.; Cooper, B.T.; Davies, J.D.; Levine, D.F. Veno-occlusive disease of the liver secondary to ingestion of comfrey. Br. Med. J. 1987, 295, 183. [CrossRef]

217. Bach, N.; Thung, S.N.; Schaffner, F. Comfrey herb tea-induced hepatic veno-occlusive disease. Am. J. Med. 1989, 87, 97-99. [CrossRef]

218. Ridker, P.M.; McDermott, W.V. Comfrey herbs tea and hepatic veno-occlusive disease. Lancet 1989, 333, 657-658. [CrossRef]

219. Miskelly, F.G.; Goodyer, L.I. Hepatic and pulmonary complications of herbal medicine (letter). Postgrad Med. J. 1992, 68, 935. [CrossRef] [PubMed]

220. Georgia, M. Hepatotoxicity due to Atractylis gummifera. Clin. Toxicol. 1988, 26, 487-493. [CrossRef]

221. McDonnell, W.M.; Bhattacharya, R.; Halldorson, J.B. Fulminant hepatic failure after use of the herbal weight-loss supplement Exilis. Ann. Intern. Med. 2009, 151, 673-674. [CrossRef] [PubMed]

222. Mostefa-Kara, N.; Pauwels, A.; Pines, E.; Biour, M.; Levy, V.G. Fatal hepatitis after herbal tea (letter). Lancet 1992, 340, 674. [CrossRef]

223. Dao, T.; Peytier, A.; Galateau, F.; Valla, A. Chronic hepatitis due to germander. Gastroenterol. Clin. Biol. 1993, 17, 614-615.

224. Mattéi, A.; Rucay, P.; Samuel, D.; Feray, C.; Michel, R.; Bismuth, H. Liver transplantation for acute liver failure after herbal medicine (Teucrium polium) administration (letter). J. Hepatol. 1995, 22, 597. [CrossRef]

225. Laliberté, L.; Villeneuve, J.P. Hepatitis after the use of germander, a herbal remedy. Can. Med. Assoc. J. 1996, $154,1689-1692$.

226. Starakis, I.; Siagris, D.; Leonidou, L.; Mazakopakis, E.; Tsamandas, A.; Karatza, C. Hepatitis caused by the herbal remedyTeucrium polium L. Eur. J. Gastroenterol. Hepatol. 2006, 18, 681-683. [CrossRef] [PubMed]

227. Strahl, S.; Ehret, V.; Dahm, H.H.; Maier, K.P. Necrotising hepatitis after taking herbal remedies. Dtsch Med. Wschr. 1998, 123, 1410-1414. (In German) [CrossRef] [PubMed]

228. Greving, I.; Meister, V.; Monnerjahn, C.; Müller, K.M.; May, B. Chelidonium majus: A rare reason for severe hepatotoxic reaction. Pharmacoepidemiol. Drug Saf. 1998, 7, S66-S69. [CrossRef]

229. Benninger, J.; Schneider, H.T.; Schuppan, D.; Kirchner, T.; Hahn, E.G. Acute hepatitis induced by Greater Celandine (Chelidonium majus). Gastroenterology 1999, 117, 1234-1237. [CrossRef]

230. Crijns, A.P.; de Smet, P.A.; van den Heuvel, M.; Schot, B.W.; Haagsma, E.B. Acute hepatitis after use of herbal preparation with greater celandine (Chelidonium majus). Ned. Tijdschr. Geneeskd 2002, 146, 124-128. (In Dutch) [PubMed]

231. Hardeman, E.; van Overbeke, L.; Ilegems, S.; Ferrante, M. Acute hepatitis induced by greater celandine (Chelidonium majus). Acta Gastroenterol. Belg. 2003, 71, 281-282.

232. Stickel, F.; Pöschl, G.; Seitz, K.H.; Waldherr, R.; Hahn, E.G.; Schuppan, D. Acute hepatitis induced by Greater Celandine (Chelidonium majus). Scand. J. Gastroenterol. 2003, 38, 565-568. [CrossRef] [PubMed]

233. Rifai, K.; Flemming, P.; Manns, M.P.; Trautwein, C. Severe drug hepatitis caused by Chelidonium majus. Internist 2006, 47, 749-751. (In German) [CrossRef] [PubMed]

234. Conti, E.; De Checchi, G.; Mencarelli, R.; Pinato, S.; Rovere, P. Lycopodium similiaplex-induced acute hepatitis: A case report. Eur. J. Gastroenterol. Hepatol. 2008, 20, 469-471. [CrossRef] [PubMed]

235. Moro, P.A.; Cassetti, F.; Giugliano, G.; Falce, M.T.; Mazzanti, G.; Menniti-Ippolito, F.; Raschetti, R.; Santuccio, C. Hepatitis from Greater celandine (Chelidonium majus L.): Review of literature and report of a new case. J. Ethnopharmacol. 2009, 124, 328-332. [CrossRef] [PubMed]

236. Tarantino, G.; Di Minno, M.N.D.; Pezullo, M.G.; Pezzullo, L.S.; Milone, F.; Milone, M.; Capone, D. Drug-induced liver injury due to "natural products" used for weight loss: A case report. World J. Gastroenterol. 2009, 15, 2414-2417. [CrossRef] [PubMed]

237. European Medicines Agency (EMA). Assessment report on Chelidonium majus L., herba. Draft. 25 November 2010. Available online: http://www.ema.europa.eu/docs/en_GB/ document_library/ Public_statement/2011/01/WC500100940.pdf (accessed on 15 March 2016).

238. Duenas Sadornil, C.; Fabregas Piugtio, S.; Durandez, R. Hepatotoxicity due to Camelia sinensis. Med. Clin. 2004, 122, 677-678. (In Spanish) 
239. Abu el Wafa, Y.; Benaventa Fernandez, A.; Talavera Fabuel, A.; Perez Ramos, M.A.; Ramos-Clemente, J.I. Acute hepatitis induced by Camellia sinensis (green tea). An. Med. Interna 2005, 22, 298. (In Spanish) [PubMed]

240. Martinez-Sierra, C.; Rendon Unceta, P.; Martin Herrera, L. Acute hepatitis after green tea ingestion. Med. Clin. 2006, 127, 119. [CrossRef]

241. Federico, A.; Tiso, A.; Loguercio, C. A case of hepatotoxicity caused by green tea. Free Radic. Biol. Med. 2007, 43, 474. [CrossRef] [PubMed]

242. Verheist, X.; Burvenich, P.; Van Sassenbroeck, D.; Gabiel, C.; Lootens, M.; Baert, D. Acute hepatitis after treatment for hair loss with oral green tea extracts (Camellia sinensis). Acta Gastroenterol. Belg. 2009, 72, 262-264.

243. Stillman, A.S.; Huxtable, R.; Consroe, P.; Kohnen, P.; Smith, S. Hepatic veno-occlusive disease due to pyrrolizidine (Senecio) poisoning in Arizona. Gastroenterology 1977, 73, 349-352. [PubMed]

244. Fox, D.W.; Hart, M.C.; Bergeson, P.S.; Jarrett, P.B.; Stillman, A.E.; Huxtable, R.J. Pyrrolizidine (Senecio) intoxication mimicking Reye syndrome. J. Pediatr. 1978, 93, 980-982. [CrossRef]

245. Dara, L.; Hewett, J.; Lim, J.K. Hydroxycut hepatotoxicity: A case series and review of liver toxicity from herbal weight loss supplements. World J. Gastroenterol. 2008, 14, 6999-7004. [CrossRef] [PubMed]

246. Hoffmann, M.; Marbet, U.A.; Hurni, A.; Bianchi, L.; Göldi, H. Rezidiv einer medikamentös-toxischen Hepatitis. Schweiz Med. Forum 2005, 5, 147-148.

247. Duque, J.M.; Ferreiro, J.; Salgueiro, E.; Manso, G. Hepatotoxicity associated with the consumption of herbal slimming products. Med. Clin. 2007, 128, 238-239.

248. Elinav, E.; Pinsker, G.; Safadi, R.; Pappo, O.; Bromberg, M.; Anis, E.; Keinan-Boker, L.; Broide, E.; Ackerman, Z.; Nitzan Kaluski, D.; et al. Association between consumption of Herbalife nutritional supplements and acute hepatotoxicity. J. Hepatol. 2007, 47, 514-520. [CrossRef] [PubMed]

249. Schoepfer, A.M.; Engel, A.; Fattinger, K.; Marbet, U.A.; Criblez, D.; Reichen, J.; Zimmermann, A.; Oneta, C.M. Herbal does not mean innocuous: Ten cases of severe hepatotoxicity associated with dietary supplements from Herbalife products. J. Hepatol. 2007, 47, 521-526. [CrossRef] [PubMed]

250. Chao, S.; Anders, M.; Turbay, M.; Olaiz, E.; Mc Cormack, L.; Mastai, R. Toxic hepatitis by consumption of Herbalife products: A case report. Acta Gastroenterol. Latinoam 2008, 38, 274-277. [PubMed]

251. Manso, G.; López-Rivaz, L.; Duque, J.M.; Salgueiro, E. Spanish reports of hepatotoxicity associated with Herbalife. J. Hepatol. 2008, 49, 289-290. Author reply 290-292. [CrossRef] [PubMed]

252. Stickel, F.; Droz, S.; Patsenker, E.; Bögli-Stuber, K.; Aebi, B.; Leib, S.L. Severe hepatotoxicity following ingestion of Herbalife nutritionally supplements contaminated with Bacillus subtilis. J. Hepatol. 2009, 50, 111-117. [CrossRef] [PubMed]

253. Jóhannsson, M.; Ormarsdóttir, S.; Olafsson, S. Hepatotoxicity associated with the use of Herbalife. Laeknabladid 2010, 96, 167-172. [PubMed]

254. Chen, G.C.; Ramanathan, V.S.; Law, D.; Funchain, P.; Chen, G.C.; French, S.; Shlopov, B.; Eysselein, V.; Chung, D.; Reicher, S.; et al. Acute liver injury induced by weight-loss herbal supplements. World J. Hepatol. 2010, 2, 410-415. [CrossRef] [PubMed]

255. Appelhans, K.; Smith, C.; Bejar, E.; Henig, Y.S. Revisiting acute liver injury associated with Herbalife products. World J. Hepatol. 2011, 3, 275-277. [CrossRef] [PubMed]

256. Manso, G.; López-Rivas, L.; Salgueiro, M.E.; Duque, J.M.; Jimeno, F.J.; Andrade, R.J.; Lucena, M.I. Continuous reporting of new cases in Spain supports the relationship between Herbalife products and liver injury. Pharmacoepidemiol. Drug Saf. 2011, 20, 1080-1087. [CrossRef] [PubMed]

257. Appelhans, K.; Frankos, V.; Shao, A. Misconceptions regarding association between Herbalife products and liver related case reports in Spain. Pharmacoepidemiol. Drug Saf. 2012, 21, 333-334. [CrossRef] [PubMed]

258. Stevens, T.; Qadri, A.; Zein, N.N. Two patients with acute liver injury associated with use of the herbal weight-loss supplement hydroxycut. Ann. Intern. Med. 2005, 14, 477-478. [CrossRef]

259. Jones, F.J.; Andrews, A.H. Acute liver injury associated with the herbal supplement hydroxycut in a soldier deployed to Iraq. Am. J. Gastroenterol. 2007, 102, 2357-2358. [CrossRef] [PubMed]

260. Shim, M.; Saab, S. Severe hepatotoxicity due to Hydroxycut: A case report. Dig. Dis. Sci. 2009, 54, 406-408. [CrossRef] [PubMed]

261. Fong, T.L.; Klontz, K.C.; Canas-Coto, A.; Casper, S.J.; Durazo, F.A.; Davern, T.J.; Hayashi, P.; Lee, W.M.; Seeff, L.B. Hepatotoxicity due to Hydroxycut: A case series. Am. J. Gastroenterol. 2010, 105, 1561-1566. [CrossRef] [PubMed] 
262. Wainwright, J.; Schonland, M.M. Toxic hepatitis in black patients in Natal. S. Afr. Med. J. 1977, 51, 571-573. [PubMed]

263. Wainwright, J.; Schonland, M.M.; Candy, H.A. Toxicity of Callilepis laureola. S. Afr. Med. J. 1977, 52, $313-315$. [PubMed]

264. Popat, A.; Shear, N.H.; Malkiewicz, I.; Stewart, M.J.; Steenkamp, V.; Thomson, S.; Neuman, M.G. The toxicity of Callilepis laureola, a South African traditional herbal medicine. Clin. Biochem. 2001, 34, 229-236. [CrossRef]

265. Fraquelli, M.; Colli, A.; Cocciolo, M.; Conte, D. Adult syncytial giant cell chronic hepatitis due to herbal remedy. J. Hepatol. 2000, 33, 505-508. [CrossRef]

266. Brauer, R.B.; Pfab, R.; Becker, K.; Berger, H.; Stangl, M. Fulminantes Leberversagen nach Einnahme des pflanzlichen Heilmittels Kava-Kava. Z Gastroenterol. 2001, 39, 30, (abstract in German).

267. Escher, M.; Desmeules, J.; Giostra, E.; Mentha, G. Hepatitis associated with kava, a herbal remedy for anxiety. Br. Med. J. 2001, 322, 139. [CrossRef]

268. Kraft, M.; Spahn, T.W.; Menzel, J.; Senninger, N.; Dietl, K.H.; Herbst, H.; Domschke, W.; Lerch, M.M. Fulminant liver failure after administration of the herbal antidepressant Kava-Kava. Dtsch Med. Wschr. 2001, 126, 970-972. (In German) [CrossRef] [PubMed]

269. Russmann, S.; Lauterburg, B.H.; Helbling, A. Kava hepatotoxicity. Ann. Intern. Med. 2001, 135, 68-69. [CrossRef] [PubMed]

270. Saß, M.; Schnabel, S.; Kröger, J.; Liebe, S.; Schareck, W.D. Akutes Leberversagen durch Kava Kava-eine seltene Indikation zur Lebertransplantation. Z. Gastroenterol. 2001, 39, 29. (In German)

271. Bujanda, L.; Palacios, A.; Silvariño, R.; Sánchez, A.; Muñoz, C. Hepatitis aguda icterica secundaria a kava. Gastroenterol. Hepatol. 2002, 25, 434-435. [CrossRef]

272. Denham, A.; McIntyre, M.; Whitehouse, J. Kava-The unfolding story: Report on a work-in-progress. J. Altern. Complement. Med. 2002, 8, 237-263. [CrossRef] [PubMed]

273. Weise, B.; Wiese, M.; Plötner, A.; Ruf, B.R. Toxic hepatitis after intake of kava-kava. Verdauungskrankheiten 2002, 4, 166-169. (In German)

274. Gow, P.J.; Connelly, N.J.; Hill, R.L.; Crowley, P.; Angus, P.W. Fatal fulminant hepatic failure induced by a natural therapy containing kava. Med. J. Aust. 2003, 178, 442-443. [PubMed]

275. Humberston, C.L.; Akhtar, J.; Krenzelok, E.P. Acute hepatitis induced by kava kava. J. Toxicol. Clin. Toxicol. 2003, 41, 109-113. [CrossRef] [PubMed]

276. Russmann, S.; Barguil, Y.; Cabalion, P.; Kritsanida, M.; Duhet, D.; Lauterburg, B.H. Hepatic injury due to traditional aqueous extracts of kava root in New Caledonia. Eur. J. Gastroenterol. Hepatol. 2003, 15, 1033-1036. [CrossRef] [PubMed]

277. Schulze, J.; Raasch, W.; Siegers, C.P. Toxicity of kava pyrones, drug safety and precautions-A case study. Phytomedicine 2003, 10, 68-73. [CrossRef] [PubMed]

278. Stickel, F.; Baumüller, H.M.; Seitz, K.; Vasilakis, D.; Seitz, G.; Seitz, H.K.; Schuppan, D. Hepatitis induced by kava (Piper methysticum rhizoma). J. Hepatol. 2003, 39, 62-67. [CrossRef]

279. Christl, S.U.; Seifert, A. Seeler D: Toxic hepatitis after consumption of traditional kava preparation. Int. Soc. Travel. Med. 2009, 16, 55-56. [CrossRef] [PubMed]

280. McGee, J.; Patrick, R.S.; Wood, C.B.; Blumgart, L.H. A case of veno-occlusive disease of the liver in Britain associated with herbal tea consumption. J. Clin. Pathol. 1976, 29, 788-794. [CrossRef] [PubMed]

281. Harvey, J.; Colin-Jones, D.G. Mistletoe hepatitis. Br. Med. J. 1981, 282, 186-187. [CrossRef]

282. Hyde, F.F. Mistletoe hepatitis. Br. Med. J. 1981, 282, 739. [CrossRef]

283. Colin-Jones, D.G.; Harvey, J. Mistletoe hepatitis. Br. Med. J. 1982, 284, 744-745. [CrossRef]

284. Farnsworth, N.R.; Loub, W.D. Mistletoe hepatitis. Br. Med. J. 1981, 283, 1058. [CrossRef]

285. Stirpe, F. Mistletoe hepatitis. Br. Med. J. 1983, 1, 29.

286. Millonig, G.; Stadlmann, S.; Vogel, W. Herbal hepatotoxicity: Acute hepatitis caused by a Noni preparation (Morinda citrifolia). Eur. J. Gastroenterol. Hepatol. 2005, 17, 445-447. [CrossRef] [PubMed]

287. Stadlbauer, V.; Fickert, P.; Lackner, C.; Schmerlaib, J.; Krisper, P.; Trauner, M.; Stauber, R.E. Hepatotoxicity of NONI juice: Report of two cases. World J. Gastroenterol. 2005, 11, 4758-4760. [CrossRef] [PubMed]

288. Yüce, B.; Gülberg, V.; Diebold, J.; Gerbes, A.L. Hepatitis induced by Noni juice from Morinda citrifolia: A rare cause of hepatotoxicity or the tip of a iceberg? Digestion 2006, 73, 167-170. [PubMed] 
289. López-Cepero Andrada, J.M.; Lerma Castilla, S.; Fernandèz Olvera, M.D.; Amaya Vidal, A. Hepatotoxicity caused by a Noni (Morinda citrifolia) preparation. Espanola de Patologia Digestiva 2007, 99, 179-181. (In Spanish)

290. Stadlbauer, V.; Weiss, S.; Payer, F.; Stauber, R.E. Herbal does not at all mean innocuous: The sixth case of hepatotoxicity associated with Morinda citrifolia (Noni). Am. J. Gastroenterol. 2008, 103, 2406-2407. [PubMed]

291. Yu, E.L.; Sivagnanam, M.; Ellis, L.; Huang, J.S. Acute hepatotoxicity after ingestion of Morinda citrifolia (Noni Berry) juice in a 14-year-old boy. J. Pedriatr. Gastroenterol. Nutr. 2011, 52, 222-224. [CrossRef] [PubMed]

292. Altan, E.; Bitik, B.; Kalpkci, Y.; Dogan, E.; Altundag, K. Probable hepatotoxicity related to Nerium oleander extract in a patient with metastatic synovial sarcoma of the knee. J. Altern. Complement. Med. 2009, 15, 113. [CrossRef] [PubMed]

293. Mokhobo, K.P. Herb use and necrodegenerative hepatitis. S. Afr. Med. J. 1976, 50, 1096-1099. [PubMed]

294. Vallance, W.B. Pennyroyal poisoning: A fatal case. Lancet 1955, 266, 850-851. [CrossRef]

295. Sullivan, J.B.; Rumack, B.H.; Thomas, H.; Peterson, R.G.; Bryson, P. Pennyroyal oil poisoning and hepatotoxicity. J. Am. Med. Assoc. 1979, 242, 2873-2874. [CrossRef]

296. Anderson, I.B.; Mullen, W.H.; Meeker, J.E.; Khojasteh-Bakht, S.C.; Oishi, S.; Nelson, S.D.; Blanc, P.D. Pennyroyal toxicity: Measurement of toxic metabolite levels in two cases and review o the literature. Ann. Intern. Med. 1996, 124, 726-734. [CrossRef] [PubMed]

297. Bakerink, J.A.; Gospe, S.M.; Dimand, R.J.; Eldridge, M.W. Multiple organ failure after ingestion of pennyroyal oil from herbal tea in two infants. Pediatrics 1996, 98, 944-947. [PubMed]

298. Joshi, D.; Cross, T.J.S.; Wong, V.S. Acute drug induced hepatitis secondary to a weight loss product purchased over the internet. Nutr. J. 2007, 6. [CrossRef] [PubMed]

299. Roselle, H.; Ekatan, A.; Tzeng, J.; Sapienza, M.; Kocher, J. Symptomatic hepatitis associated with the use of herbal Red Yeast Rice. Ann. Intern. Med. 2008, 149, 516-517. [CrossRef] [PubMed]

300. Larrey, D. Hepatotoxicity of herbal remedies. J. Hepatol. 1997, 26, 47-51. [CrossRef]

301. Lapi, F.; Gallo, E.; Giocaliere, E.; Vietri, M.; Baronti, R.; Pieraccini, G.; Tafi, A.; Menniti-Ippolito, F.; Mugelli, A.; Firenzuoli, F.; et al. Acute liver damage due to Serenoa repens: A case report. Br. J. Clin. Pharmacol. 2010, 69, 558-560. [CrossRef] [PubMed]

302. MacGregor, F.B.; Abernethy, V.E.; Dahabra, S.; Cobden, I.; Hayes, P.C. Hepatotoxicity of herbal remedies. Br. Med. J. 1989, 299, 1156-1157. [CrossRef]

303. Caldwell, S.H.; Feeley, J.W.; Wieboldt, T.F.; Featherston, P.L.; Dickson, R.C. Acute hepatitis with use of over-the-counter herbal remedies. Va Med. Q. 1994, 121, 31-33. [PubMed]

304. Hullar, T.E.; Sapers, B.L.; Ridker, P.M.; Judkins, R.L.; Huth, T.S.; Farraye, F.A. Herbal toxicity and fatal hepatic failure (letter). Am. J. Med. 1999, 106, 267-268. [PubMed]

305. Beuers, U.; Spengler, U.; Pape, G.R. Hepatitis after chronic abuse of senna. Lancet 1991, 337, $372-373$. [CrossRef]

306. Seybold, U.; Landauer, L.; Hillebrand, S.; Goebel, F.D. Senna-induced hepatitis in a poor metabolizer. Ann. Intern. Med. 2004, 141, 650-651. [CrossRef] [PubMed]

307. Vanderperren, B.; Rizzo, M.; Angenot, L.; Haufroid, V.; Jadoul, M.; Hantson, P. Acute liver failure with renal impairment related to the abuse of Senna anthraquinone glycosides. Ann. Pharmacother. 2005, 39, 1353-1357. [CrossRef] [PubMed]

308. Mennecier, D.; Saloum, T.; Dourthe, P.M.; Bronstein, J.A.; Thiolet, C.; Farret, O. Acute hepatitis after phytotherapy. Présse Med. 1999, 28, 966. [PubMed]

309. De Smet, P.A.G.M.; van den Eertwegh, A.J.M.; Lesterhuis, W.; Stricker, B.H.C. Hepatotoxicity associated with herbal tablets. BMJ 1996, 313, 92. [CrossRef] [PubMed]

310. Takegoshi, K.; Tohyama, T.; Okuda, K.; Suzuki, K.; Ohta, G. A case of Venoplant-induced hepatic injury. Gastroenterol. Jpn. 1986, 21, 62-65. [PubMed]

311. Mathieu, N.; Bouallegue, L.; Mognol, P.; Vallot, T.; Soule, J.C. Hepatic toxicity probably due to X-elles in phytotherapy. Gastroenterol. Clin. Biol. 2005, 29, 1188-1189. [CrossRef]

312. Hayashi, P.H.; Fontana, R.J.; Chalasani, N.P.; Stolz, A.A.; Talwalkar, J.A.; Navarro, V.J.; Lee, W.M.; Davern, T.J.; Kleiner, D.E.; Gu, J.; et al. Under-reporting of poor adherence to monitoring guidelines for severe cases of Isoniazid hepatotoxicity. Clin. Gastroenterol. Hepatol. 2015, 13, 1676-1682. [CrossRef] [PubMed] 
313. Chalasani, N.P.; Hayashi, P.H.; Bonkovsky, H.L.; Navarro, V.J.; Lee, W.M.; Fontana, R.J. ACG Clinical guideline: The diagnosis and management of idiosyncratic drug-induced liver injury. Am. J. Gastroenterol. 2014, 109, 950-966. [CrossRef] [PubMed]

314. Mohabbat, O.; Younos, M.S.; Merzad, A.A.; Srivastava, R.N.; Sediq, G.G.; Aram, G.N. An outbreak of hepatic veno-occlusive disease in north-western Afghanistan. Lancet 1976, 308, 269-271. [CrossRef]

315. Kakar, F.; Akbarian, Z.; Leslie, T.; Mustafa, M.L.; Watson, J.; van Egmond, H.P.; Omar, M.F.; Mofleh, J. An outbreak of hepatic veno-occlusive disease in western Afghanistan associated with exposure to wheat flour contaminated with pyrrolizidine alkaloids. J. Toxicol. 2010, 313280. [CrossRef] [PubMed]

316. Tandon, R.K.; Tandon, B.N.; Tandon, H.D. Study of an epidemic of venoocclusive disease in India. Gut 1976, 17, 849-855. [CrossRef] [PubMed]

317. Tandon, B.N.; Tandon, H.D.; Tandon, R.K.; Narndranathan, M.; Joshi, Y.K. An epidemic of veno-occlusive disease of the liver in central India. Lancet 1976, 308, 271-272. [CrossRef]

(C) 2016 by the authors; licensee MDPI, Basel, Switzerland. This article is an open access article distributed under the terms and conditions of the Creative Commons Attribution (CC-BY) license (http://creativecommons.org/licenses/by/4.0/). 